This item was submitted to Loughborough's Research Repository by the author.

Items in Figshare are protected by copyright, with all rights reserved, unless otherwise indicated.

\title{
Potential of microneedle-assisted micro-particle delivery by gene guns: a review
}

PLEASE CITE THE PUBLISHED VERSION

http://dx.doi.org/10.3109/10717544.2013.864345

PUBLISHER

(c) Informa Healthcare USA, Inc.

VERSION

AM (Accepted Manuscript)

LICENCE

CC BY-NC-ND 4.0

REPOSITORY RECORD

Zhang, Dongwei, Diganta Bhusan Das, and Chris D. Rielly. 2014. "Potential of Microneedle-assisted Microparticle Delivery by Gene Guns: A Review”. figshare. https://hdl.handle.net/2134/14349. 
This item was submitted to Loughborough's Institutional Repository (https://dspace.lboro.ac.uk/) by the author and is made available under the following Creative Commons Licence conditions.

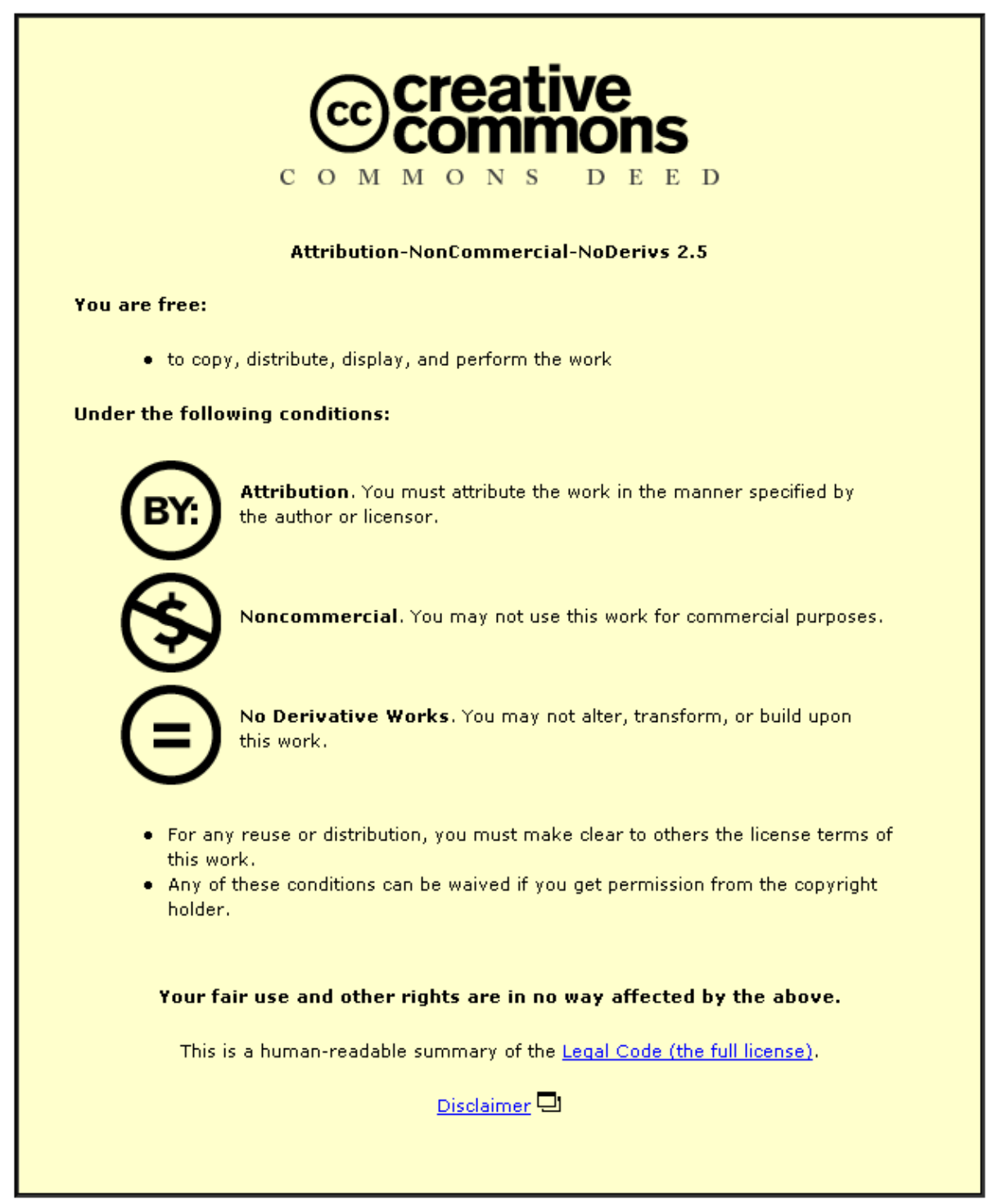

For the full text of this licence, please go to: http://creativecommons.org/licenses/by-nc-nd/2.5/ 


\title{
Potential of microneedle assisted micro-particle delivery by gene guns: A review
}

\author{
Dongwei Zhang, Diganta B Das*, Chris D Rielly \\ Department of Chemical Engineering, Loughborough University, Loughborough \\ LE113TU, Leicestershire. UK
}

Running title: Microneedle assisted micro-particle delivery

Accepted in 'Drug Delivery'

6 November 2013

*Corresponding Author (Email: d.b.das@lboro.ac.uk) 
1 Potential of microneedle assisted micro-particle delivery by gene guns:

4

\section{Abstact}

10

11

\section{Context}

\section{Objective}

\section{Method}

\section{Results}

A review

\author{
Dongwei Zhang, Diganta B Das*, Chris D Rielly
}

Department of Chemical Engineering, Loughborough University, Loughborough LE113TU, Leicestershire. UK

( ${ }^{\star}$ Corresponding Author; Email: d.b.das@lboro.ac.uk)

Gene guns have been used to deliver deoxyribonucleic acid (DNA) loaded micro-particle and breach the muscle tissue to target cells of interest to achieve gene transfection.

This paper aims to discuss the potential of microneedle (MN) assisted micro-particle delivery from gene guns, with a view to reducing tissue damage.

Using a range of sources, the main gene guns for micro-particle delivery are reviewed along with the primary features of their technology, e.g., their design configurations, the material selection of the micro-particle, the driving gas type and pressure. Depending on the gene gun system, the achieved penetration depths in the skin are discussed as a function of the gas pressure, the type of the gene gun system, and particle size, velocity and density. The concept of $\mathrm{MN}$-assisted micro-particles delivery which consists of three stages (namely, acceleration, separation and decoration stage) is discussed. In this method, solid MNs are inserted into the skin to penetrate the epidermis/dermis layer and create holes for particle injection. Several designs of MN array are discussed and the insertion mechanism is explored, as it determines the feasibility of the MN based system for particle transfer.

The review suggests that one of the problems of gene guns is that they need high operating pressures, which may result in direct or indirect tissue/cells damage. MNs seem to be a 
31 promising method which if combined with the gene guns may reduce the operating pressures

32 for these devices and reduce tissue/cell damages.

\section{Conclusions}

34 There is sufficient potential for MN-assisted particle develivery systems.

Key words: gene gun, microneedle, micro-particle, skin, penetration depth

\section{Introduction}

39 A gene gun, involving "particle bombardment" or "biolistic delivery" is a particle accelerator, 40 which can deliver deoxyribonucleic acid (DNA) loaded micro-particles at sufficiently high

41 velocities to breach the surface of target tissue and to penetrate to a depth to achieve gene transfection in the cells. A gene gun is considered to be a unique concept which was first used to deliver genetic materials into plant cells (Klein et al., 1987; Klein et al., 1992; Sanford et al., 1993; Svarovsky, 2008; Huang et al., 2011; O'Brien et al., 2011; Manjila et al., 2013). The technique has been used to transfer DNA-coated micro-particles to achieve gene transfection into many types of cells and organs (e.g., Meacham et al., 2013; Bennett et al., 1999), for example, mammals (Cao et al., 2013; Ettinger et al., 2012; Da'dara et al., 2002; Kuriyama et al., 2000; Sakai et al., 2000; Williams et al., 1991), plants (Kuriakose et al., 2012; Zuraida et al., 2010; Klein et al., 1992), artificially cultured cells (O'Brien and Lummis, 2011, 2006), fungi (Gu et al., 2011; Armaleo et al., 1990) and bacteria (Nagata et al., 2010; Smith et al., 1992). A

51 number of commercial gene guns have been manufactured and used for in vivo gene 52 transfection in plants, living animals, cultured cells, e.g., the PowderJect system developed originally by the University of Oxford (UK) (Bellhouse et al., 2006), the Helios gene gun by

54 Bio-rad, Hercules, CA (USA) (Belyantseva, 2009), and the SJ-500 portable gene gun by 55 Biotech instrument, New Jersey (USA). The Helios and portable gene guns are shown in Figure 1. In a research context, Da'dara et al. (2002) have used a Helios gene gun to delivery

57 Sm23-pcDNA (an integral membrane protein) to mice to evaluate the immunogenicity of the 58 protective efficacy of the DNA vaccination. Ahlen et al. (2013) have used a Helios gene gun to explore a method for monitoring hepatitis $B$ and $C$ viruses (HBV/HCV) specific to immune responses in mouse.

61 
63 using this technology, as discussed by Zhao et al. (2012); O'Brien and Lummis (2006, 2011),

64 Rao (2010), Satish, (2009), Svarovsky et al. (2008), and Thomas et al. (2001). However, a

65 detailed discussion on these issues is outside the scope of this paper.

66

67 Such guns have been proposed for gene delivery in the treatment of some of the major 68 diseases such as cancer (Nguyen-Hoai et al., 2012; Aravindaram et al., 2009; Han et al., 2002;

69 Chen et al., 2002); these researchers have fired gene loaded micro-particles into mammalians 70 or cultured cells instead of humans to study gene expression and cell damage. For example, 71 Yoshida et al. (1997) used a gene gun to deliver DNA coated Au micro-particles into the liver 72 of living rat at 250 psi ( 17.2 bar) pressure, which resulted in a good gene expression but 73 caused a number of cell deaths. The work also showed that cell damage was not obtained 74 below 150 psi of pressure. Sato et al. (2000) have used various types of gene guns to transfer 75 genes into live rodent brain tissue, which confirmed gene expression, but with mechanical 76 damage to cells. Uchida et al. (2009) have fired plasmid DNA into cultured mammalian cells 77 (e.g., human embryonic kidney (HEK293) cell, human breast adenocarcinoma (MCF7) cell) 78 using a gene gun, which showed that transfection is achieved in the cells, but the cell damage 79 occurs at operating pressures greater than 200 psi ( 13.8 bar). O'Brien and Lummis (2011) 80 have cultured HEK293 cells as a target for the biolistic transfection using a gene gun. Their 81 work showed that nano-particles gave a similar performance to micro-particles for biolistic transfection, but created less cell damage.

83

84 The above works show that cell damage may be a problem for biolistic micro-particle delivery, 85 due to significant gas and particle impactions on the tissue. This also means that while gene 86 guns have been reported to be successful in many instances, they may have some disadvantages. Generally, for most gene gun systems, the maximum penetration of the 88 micro-particle can breach the stratum corneum and end inside the epidermis layer of the tissue 89 (Yager et al., 2013; Liu, 2006; Quinlan et al., 2001; Bennett et al., 1999). The epidermis layer 90 is normally considered to be a target site for gene delivery due to its accessibility (Soliman et 91 al., 2011b; Liu, 2006; Quinlan et al., 2001; Trainer and Alexander, 1997). However, a high 

the pressurized gas on the skin.

94
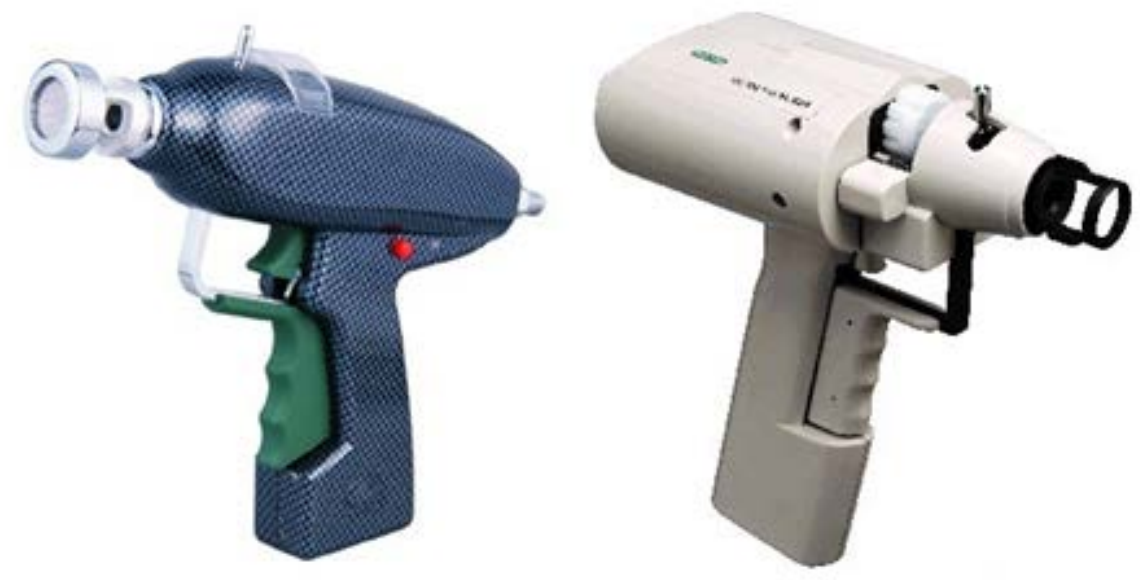

95

111 MN assisted micro-particle delivery seems to be a promising approach for dry particulate 112 delivery, but the potential of this method needs to be discussed thoroughly as it is still at an

Figure 1: Left: The commercial hand-held gene gun of SJ-500 (Biopex, 2012), Right: the commercial Helios gene gun (Bio-rad, 2012)

Cell damage can be reduced by decreasing the particle size and/or operating pressure, as both reduce the impact forces. In order to satisfy these conditions and, possibly, increase the penetration depth of the micro-particle in the target, an innovative concept of combining MNs with a particle delivery system, namely $\mathrm{MN}$-assisted micro-particle delivery, has been proposed recently by Zhang et al. (2013). The MNs are discussed in section 3 of this paper. The operating principle of the delivery in the approach of Zhang et al. (2013) is that a pellet of micro-particles is loaded on a ground slide which is accelerated by a pressurized gas to a sufficient velocity. The pellet is released after the ground slide reaches the end of a barrel in the system, and separates into micro-particles of a narrow size distribution by impaction on an open mesh; these separated micro-particles then penetrate into the desired target. The resistance of the target/skin to the penetration of the micro-particles is reduced by using MN to create a number of holes through which the micro-particles can enter, without the need for very high gas pressures. early stage of development. To this end, the main types of gene gun systems for micro-particle delivery and their operating principles are reviewed. The micro-particle material and size for 
115 these gene guns are discussed, and the range of gas pressures and particle velocities are 116 considered.

118 In this paper, MN arrays are discussed to understand how various geometries affect 119 penetration of the target material and formation of holes, which remain after the needles are 120 removed. This discussion provides relevant background knowledge and a sound foundation 121 for further improvement of gene gun systems, with the help of MN assisted micro-particle 122 delivery to achieve similar levels of penetration depth, but with less cell damage. To further 123 understand the advantage of MN assisted micro-particle delivery, a comparison with other 124 physical cell targeting approaches is discussed. Finally, some simplified models of the 125 micro-particle delivery in the skin are described, which will be useful in predicting the 126 penetration depths achieved by MN assisted gene gun delivery.

\section{Main gene guns}

\subsection{Configurations and operating conditions}

130 Based on the principles of the operation process and driving forces, we define that the gene 131 guns can be divided into three types, namely: powder gene gun, high-voltage electric gene 132 gun and gas gene gun.

134 A powder gene gun is the original device which uses an ignition gunpowder as a driving force 135 to promote the movement of bullets of macro-projectiles, thus accelerating the micro-particles 136 which are loaded onto the bullet (Huang et al., 2011; O'Brien and Lummis, 2007; Zhou, 1995; 137 Klein et al., 1987; Sanford et al., 1987). An electric gene gun uses a high voltage (HV) to 138 vaporize water droplets; the expanding gas is used to achieve the acceleration of 139 micro-particles (Christou et al., 1990). A gas gene gun releases a high pressure gas to 140 accelerate the micro-particles (or micro-particles loaded ground slide) to a sufficient velocity to 141 breach the barrier of the target (Zhang et al., 2013; Soliman et al., 2011b; Liu, 2007; Kendall et 142 al., 2002; Zhou, 2000).

144 Powder gene guns were originally developed to deliver genetic material coated micro-particles 145 into plant cells (Klein et al., 1987; Klein et al., 1992; Svarovsky, 2008; O'Brien et al., 2011; 146 Manjila et al., 2013). As shown in Figure 2, an explosion of gun powder accelerates 
DNA-coated micro-particles attached onto the front surface of o macro projectile. Klein et al.

148 used tungsten micro-particles of $4 \mu \mathrm{m}$ average diameter, which could be accelerated to 400 $\mathrm{m} / \mathrm{s}$. However, the explosion of the gun powder is noisy and may cause cell/tissue damage.

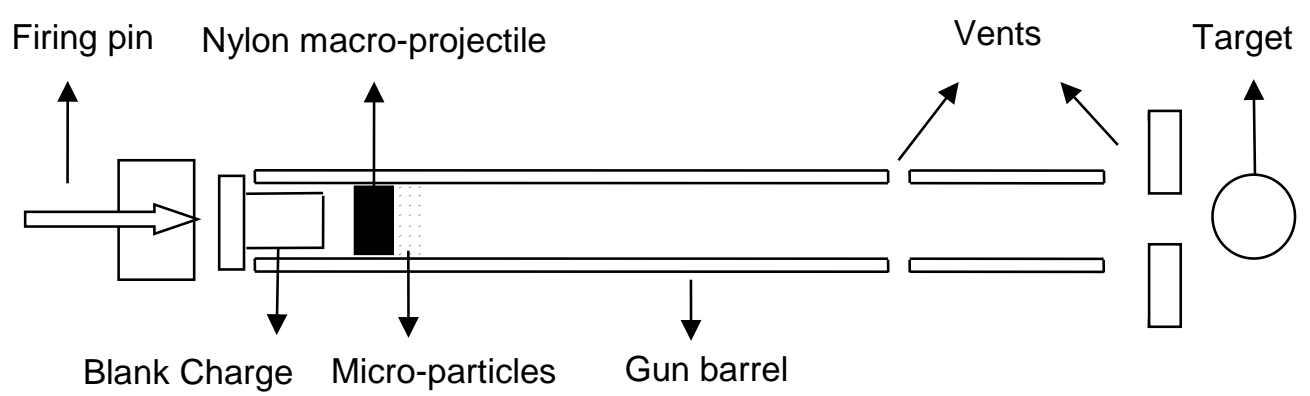

Figure 2: A schematic sketch of the powder gun (redrawn from Klein et al. (1987)) fixed pipe. An ignition of gunpowder, caused the bullet to accelerate and hit a ground slide, which then impacts on a baffle plate. Thus, the micro-particles gain an initial velocity to leave the ground slide, pass through the central hole of the baffle plate and penetrate into the tissue. The advantage of this powder gene gun is that the use of ground slide can reduce explosion damage to tissue. The base is designed as a shock absorber to reduce the recoil force, using a spring attached to the firing pin.

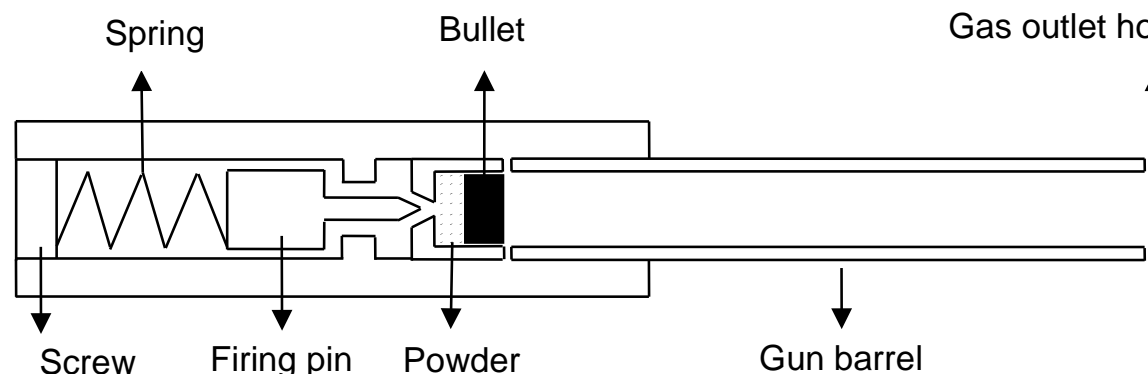

162 Christou et al. (1990) have used a type of electronic gene gun to deliver DNA-coated gold 163 micro-particles into soybean seeds; a schematic sketch of the high-voltage electric gene gun is 164 shown in Figure 4. Yang et al. (1990) have applied an electronic gene gun to transfer genes 
into the muscle, tissue and liver of a mouse, using 1-3 $\mu \mathrm{m}$ diameter golden particles. The disadvantage of their gun is that a high voltage up to $18 \mathrm{kV}$ is required to deliver a micro-particle penetration depth of $125 \mu \mathrm{m}$. Recently, Ikemoto et al. (2012) used a type of

168 high-voltage electric gene gun, namely, an electrospray device to accelerate liquid droplets in

169 a high voltage (12 kV) to collide with DNA coated micro-particles and deliver them into living 170 cells.

172 Gas gene guns can be classified into two different delivery methods. The first uses a high 173 pressure gas to push the micro-particle coated ground slide to achieve the goal of particle 174 acceleration. The disadvantage is that a very high operating pressure is required to achieve 175 the desired micro-particle impact velocity. However, the advantage is that the ground slide 176 prevents the released gas from impacting on tissue. The second method mainly uses a high 177 pressure gas (e.g., $\mathrm{N}_{2}, \mathrm{He}$ ) to directly push the DNA-coated micro-particles to a sufficient 178 velocity to breach the stratum corneum, penetrate into the epidermis/dermis layer of the skin or 179 deeper tissues. The disadvantage is that very high gas pressure may damage the tissue and 180 the muscles. The advantage is that the micro-particle can reach a desired velocity under lower 181 operation pressure as the micro-particles have very small mass.

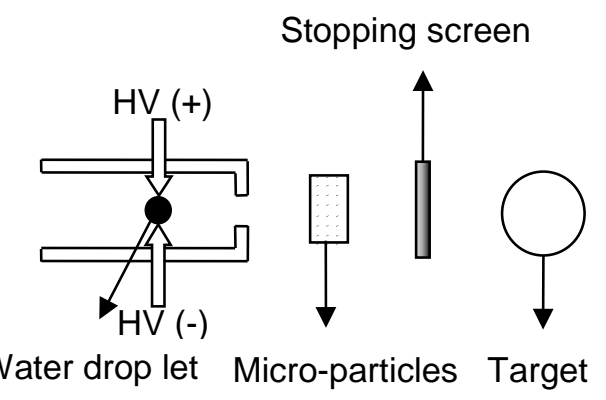

183 Figure 4: The schematic sketch of the high-voltage electric gene gun (redrawn from Christou et 184 al. (1990))

185 Using the principles of the first delivery method, Zhou (2000) has invented a kind of 186 high-pressure gene gun which consists of a casing, the compressed gas inlet pipe, emitting 187 cavity and bombarding cavity. The schematic diagram of this gun is shown in Figure 5 which 188 shows both the states of the gun before and after operation. The emitting cavity consists of an 189 air storage house, membrane, bullet, baffle plate and sample holder. The membrane will be 
ruptured when the air storage house reaches a certain pressure. High pressure gas is able to

191 accelerate the bullet to the baffle plate. Since the bullet is blocked by the baffle plate, the coated particles will leave the surface of the bullet, go through the centre hole of the baffle 193 plate and launch into the sample, thus completing the gene injection. In addition, the gas will 194 be released from the vent hole. It has been claimed that this instrument has good stability, high efficiency, does not produce impurities, and particles can also attain a higher initial speed. However, it is generally applied for plant tissues.

Mitchell et al. (2003) have conducted many experimental and numerical studies on the light gas gun (LGG), as shown schematically in Figure 6. The LGG uses a high pressure helium gas to drive the micro-particle coated ground slide to a certain velocity. In this case, the polystyrene particles of $99 \mu \mathrm{m}$ diameter have been used and the impact velocities of the particles have been shown to reach 170, 250 and $330 \mathrm{~m} / \mathrm{s}$ under 20, 40 and 60 bar operation pressures.

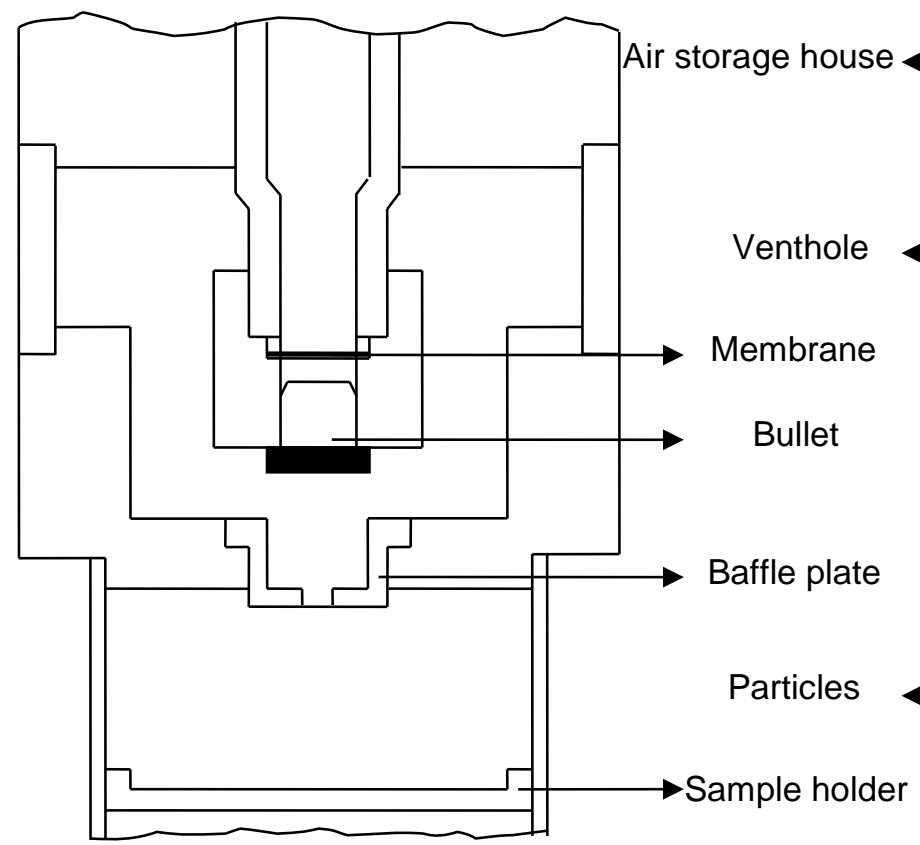

A

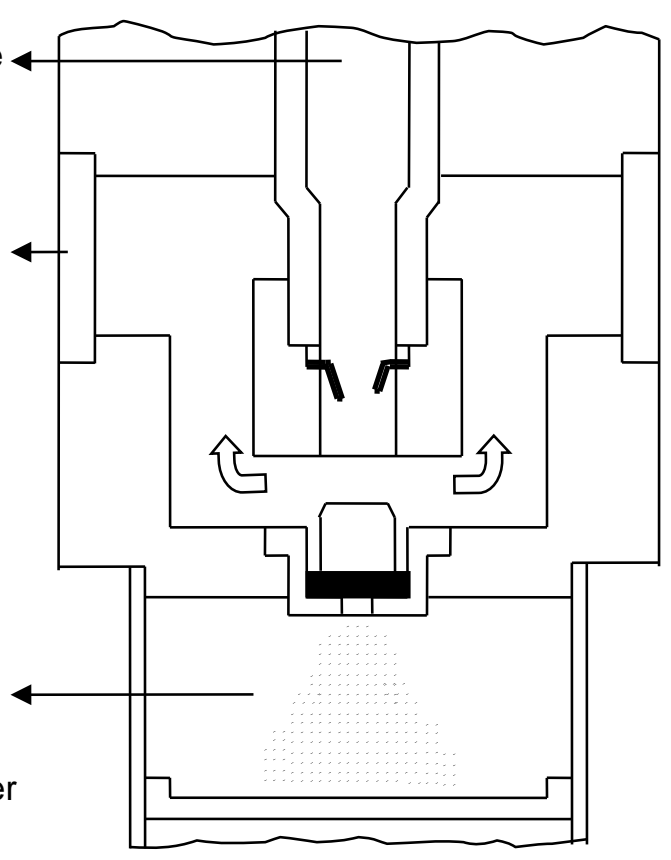

B

Figure 5: The schematic diagram and principle of high-pressure gas gene gun (redrawn from Zhou (2000)) 
Compressed gas Ground slide

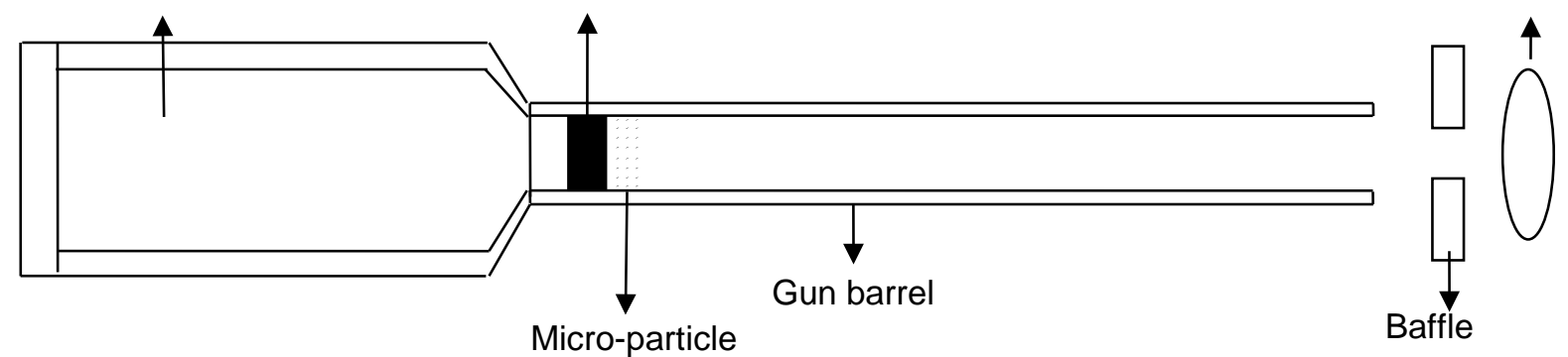

Figure 6: The schematic sketch of light gas gun (redrawn from Mitchell et al. (2003))

210 Williams et al. (1991) have studied a helium-driven gene gun which is somewhat similar to the

211 design of Zhou's (2000), as shown in Figure 7. In this case, a membrane in the system breaks

212 after the gas pressure reaches a certain value. The micro-projectiles are accelerated by the

213 helium gas and separated well by a stopping screen. In addition, the large particle is blocked

214 by a screen to avoid tissue damage. In this case, golden particles of $1-3 \mu \mathrm{m}$ and $2-5 \mu \mathrm{m}$

215 diameters have been fired and penetration depths of $150 \mu \mathrm{m}$ and $200 \mu \mathrm{m}$ have been obtained

216 in a mouse liver, under 1300 psi operating pressure.

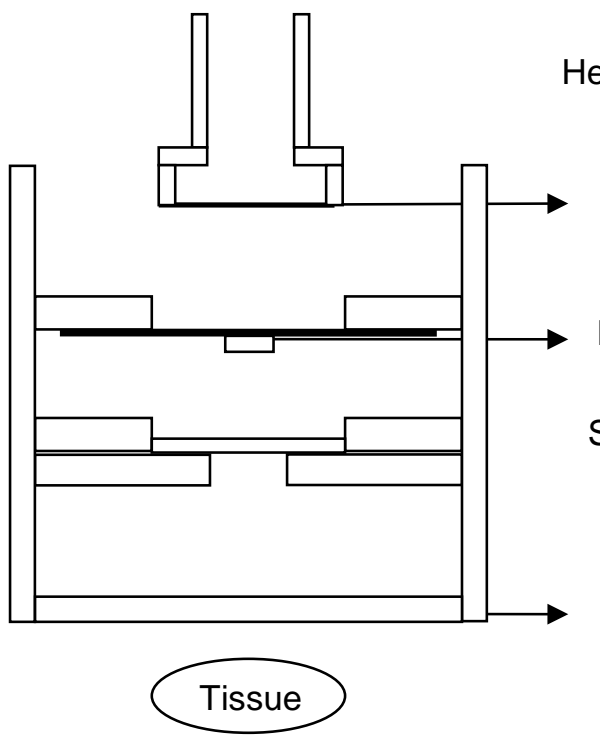

Helium gas inlet

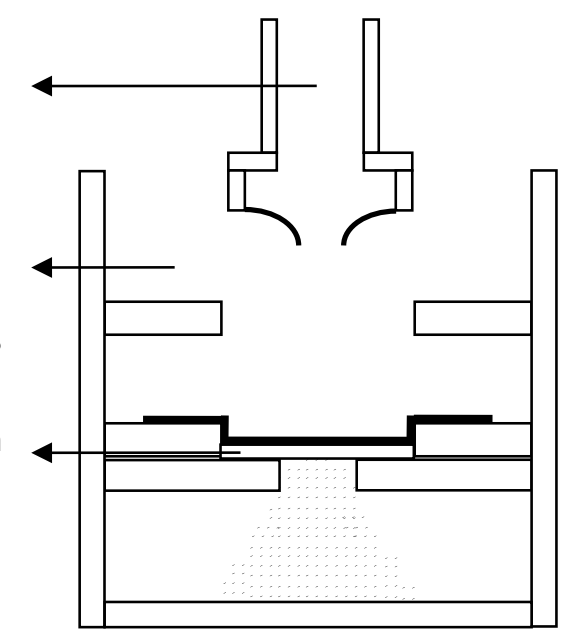

Screen

Tissue

Figure 7: The schematic sketch of helium-driven gene gun (redrawn from Williams et al.

(1991))

221 Kendall (2002) has reported a contoured shock tube which is shown in Figure 8. In this case,

222 the compressed gas will pressurize the membrane, and the micro-particle will be accelerated 
by a shock wave as the gas pressure rises to the point where the membrane ruptures. Liu et al. (2004a) and Liu (2006) have described an injection device, namely PowderJect (Figure 9), which uses helium gas as the source of momentum. A trigger actuates a mechanism to release helium gas, which expanded to accelerate the micro-particles to a sufficient momentum to pierce the outer layer of the target and into the cells of interest.

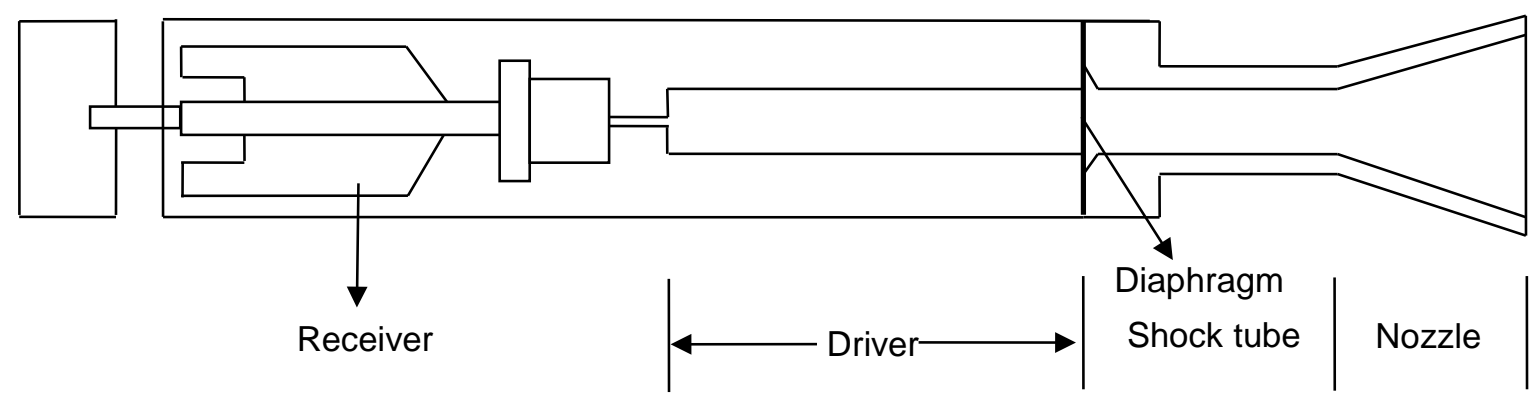

Figure 8: The schematic diagram of contoured shock tube (redrawn from Kendall (2002))

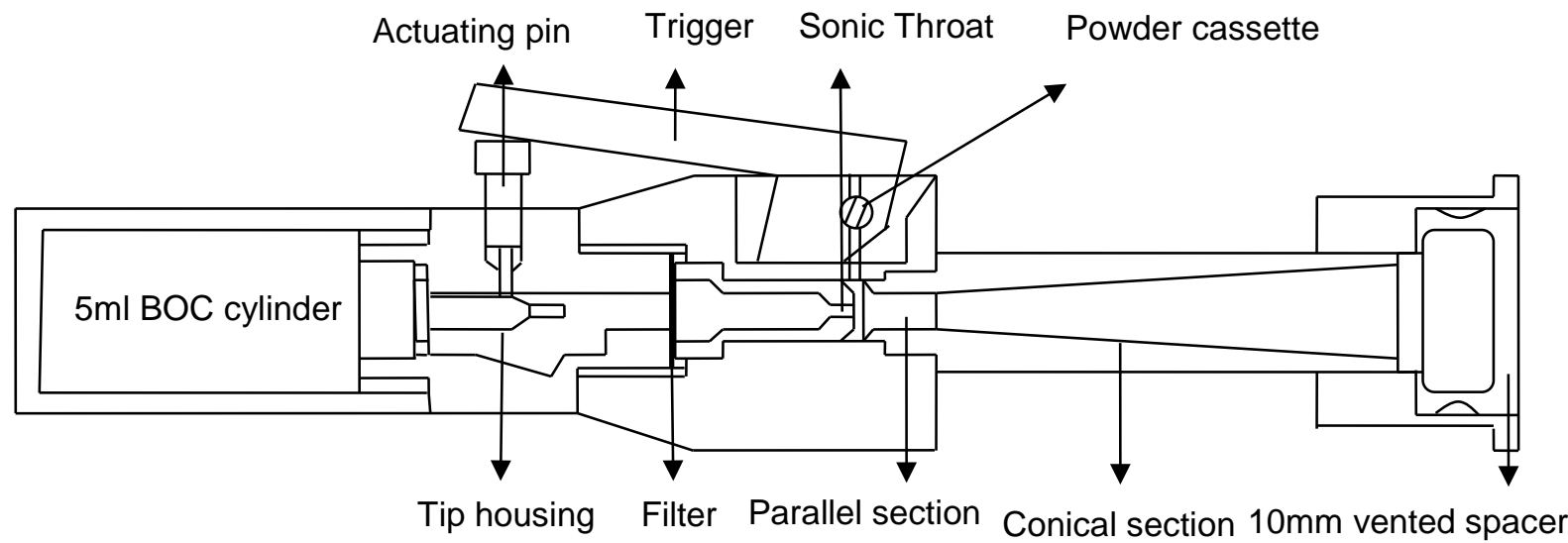

Figure 9: A schematic diagram of the PowderJect system (redrawn from Liu (2006))

Zhang et al. (2007) have introduced the principle of the Helios gene gun which contains acceleration, separation and deceleration stages. The process of micro-particle delivery is shown in Figure 10. This gene gun uses helium gas to accelerate DNA-coated micro-carriers which are separated by a stopping screen. The separated micro-particles exit from the gene gun at high speed, penetrate the tissue to the targeting area, enter into the cell and hit the nucleus membrane. 


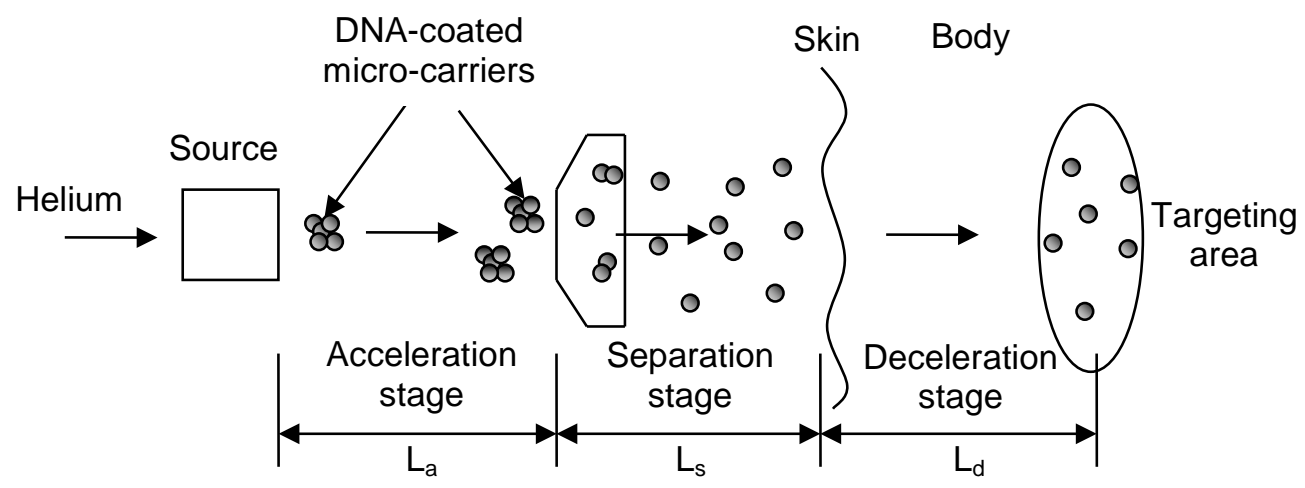

Figure 10: Gene transfer stages of the biolistic gene gun (redrawn from Zhang et al. (2007)); $\mathrm{L}_{\mathrm{a}}$,

$241 L_{s}$ and $L_{d}$ are the distance of acceleration, separation and deceleration stages.

243 In addition, Zhou (2007) has created a special liquid gene sprayer (Figure 11) which is 244 different from the above three gene gun types. It has been used to deliver liquid-form 245 medication into the human body and consists of an interconnected casing and magazine. The magazine comprises of a hollow cylinder and sliding piston rod set; emission holes are

247 arranged at the front end of the cylinder and the front end of the casing is fixed to rear end opening. An energy-storage driving mechanism consists of a spring and impeller and set in the internal cavity of the casing. The impeller moves backward to press the spring to store the energy, and pushes forward by a driving force from the released spring. This device uses a

251 small volume energy storage device to inject the required amount of biological gene, and does not need any separate air supply equipment; it is easy to handle and carry. It uses the liquid as

253 the DNA particle's carrier and hence golden particles are not required in this device. The DNA 254 particles will be suspended in the liquid. Before using this device, the head of the hollow 255 cylinder is inserted into the DNA particle coated liquid, and the sliding piston rod is pulled out 256 to extract the liquid and load the gun. Then the spring is compressed very tightly, storing 257 energy (see Figure 11a), which is released to accelerate the impeller and sliding piston rod; 258 then the DNA particle coated with liquid are pushed out from the emission hole and penetrate 259 into the tissue of plant or human to the target cells of interest. The state of the liquid gene gun after injection is shown in Figure 11b. 


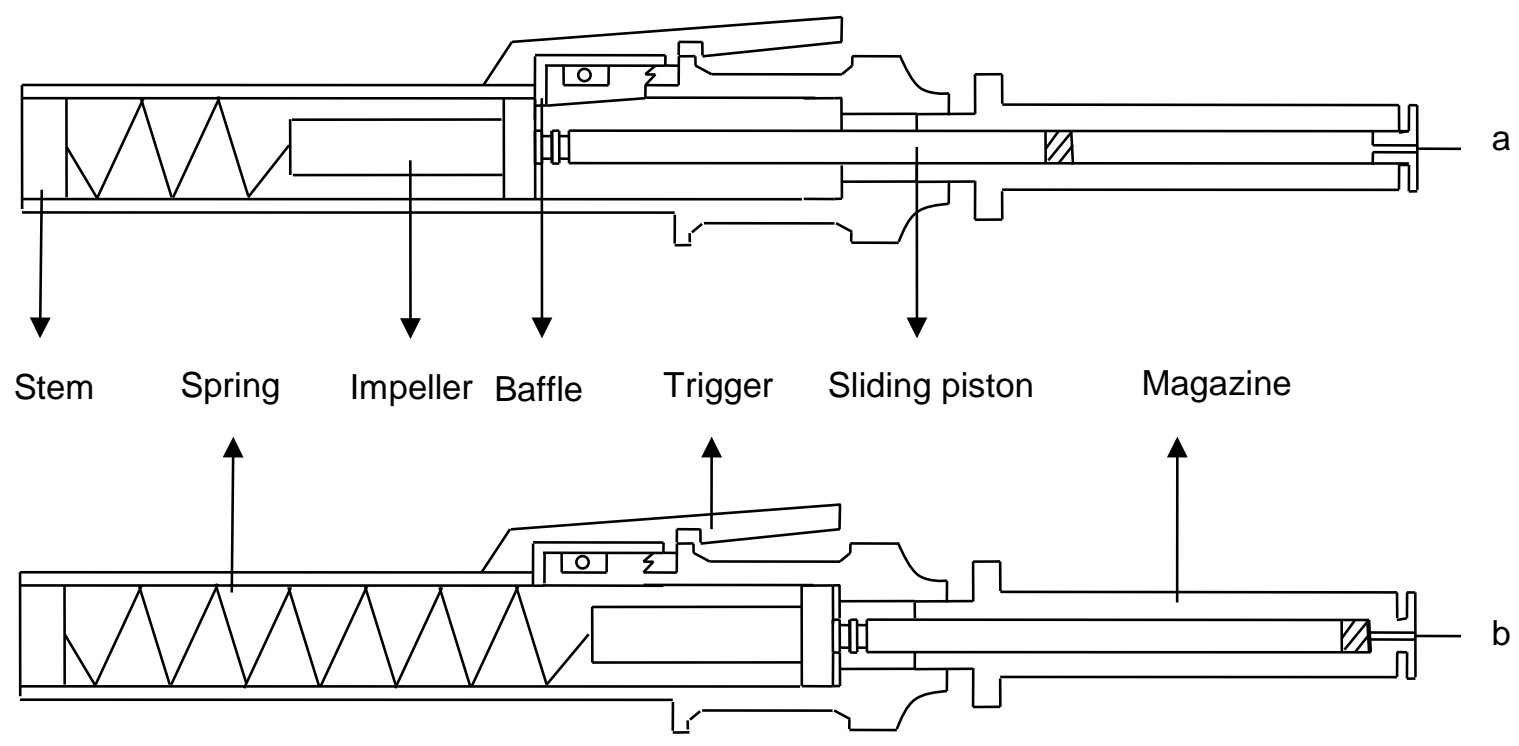

262 Figure 11: The liquid gene sprayer: A: The liquid gene gun at energy storage state, B: The 263 state of liquid gene gun after injection (redrawn from Zhou (2007))

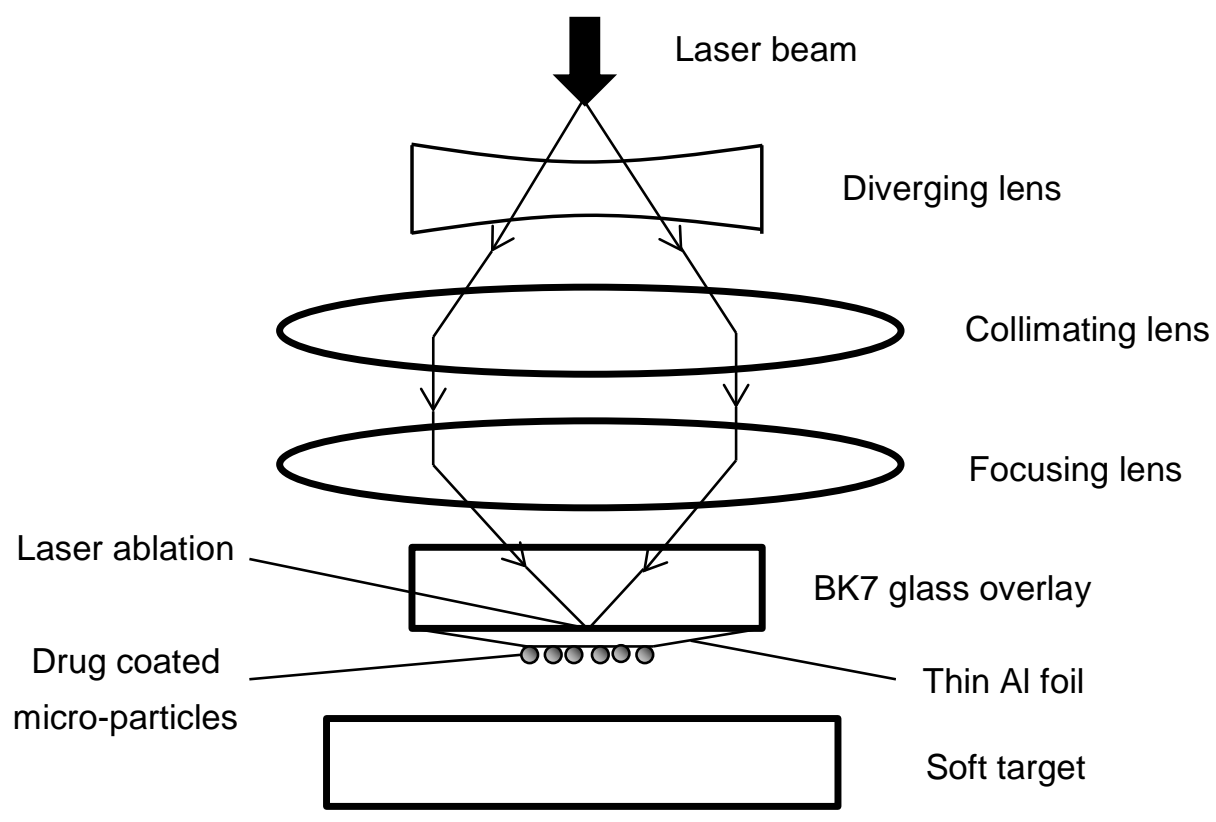

265 Figure 12: The schematic of the laser plasma jet (redrawn from Menezes et al. (2012))

Recently, Menezes et al. (2012) have designed an advanced laser plasma jet (see Figure 12) to deliver DNA-coated micro-particle. The operating principle is that a laser beam is fired and ablates a thin aluminum foil, using lenses for focusing. The laser ablation is confined by the BK7 glass overlay to improve performance. Thus, it causes the foil to evaporate into an ionized 271 vapor and the sudden blow-off causes a shock wave to breach the foil to accelerate DNA 
272 coated micro-particles. The device provides micro-particles impact velocities of up to $1100 \mathrm{~m} / \mathrm{s}$,

273 which is faster than other gen guns (e.g. CST, LLG). However, this technique is costly due to

274 the use of laser ablation.

275

\section{$276 \quad 2.2$ Micro-particle materials and size}

277 The materials and size of the micro-particles which are used in gene guns have significant 278 importance on the operation of the system, e.g. by determining the routes and extent of 279 particle penetration into tissue. In general, the routes of the micro-particle penetration in the 280 tissue are normally divided into two types, which are the extracellular and intercellular routes 281 (Bryan et al., 2013; Soliman, 2011; Mitchell et al., 2003). As presented in Figure 13(a-b), the 282 penetration routes of the micro-particles in tissue depend on the particle size. The extracellular 283 route is followed for large particle delivery, e.g., for epidermal powder immunization (Soliman, 284 2011; Hardy et al., 2005). An illustration of the range of particle material and sizes for the 285 relevant gene gun systems is listed in Table 1. It shows that the extracellular route is normally 286 followed for the less dense materials (e.g., stainless steel, polystyrene and glass) with 287 diameters ranging from 15 to $99 \mu \mathrm{m}$. Hardy et al. (2005) have reported that particle diameters 288 ranging from 25 to $100 \mu \mathrm{m}$ are expected to follow the extracellular route, as their momentum is 289 insufficient to breach the target barrier of target, due to the combination of relatively low 290 density and small size. It has been recommended that stainless steel or polymer 291 micro-particles should be used for extracellular routes, due to their biocompatibility and low 292 cost (Soliman, 2011; Sung et al., 2011; Singh and Dahotre, 2007; Binyamin et al., 2006; Disegi 293 et al., 2000). 
Impact Direction

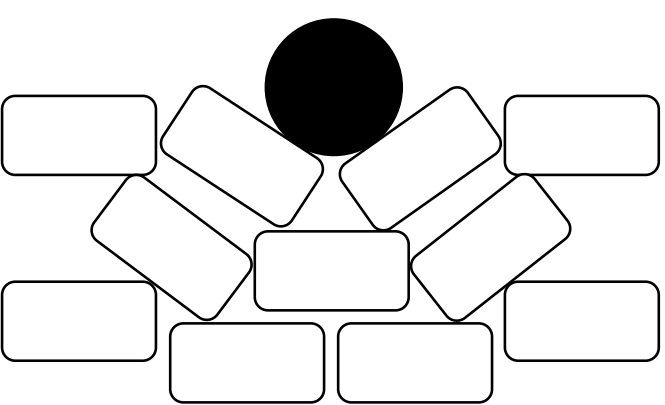

(a)

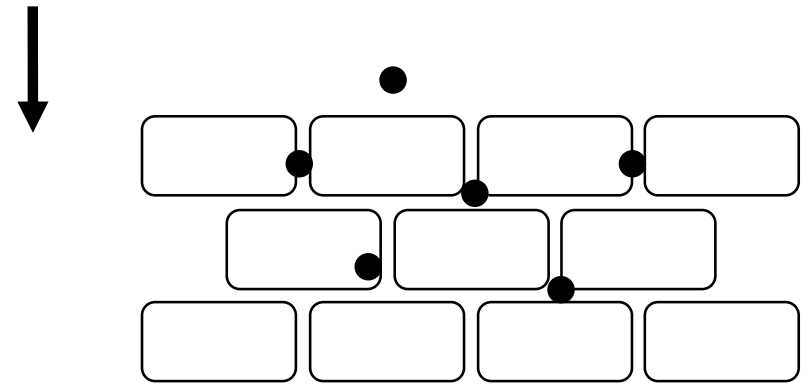

(b)

Figure 13: Schematic diagram of the extracellular and intercellular failure mechanisms (a): extracellular failure mechanism for large particles (b): intercellular failure mechanism for small particles (redrawn from Mitchell et al. (2003)).

In contrast, the intercellular route (e.g. for DNA immunization), uses smaller size, but much more dense gold or tungsten micro-particles (Soliman, 2011; Mitchell et al., 2003). In order to deliver DNA into cells effectively, dense materials are preferred which are prepared into micro-particles of diameters ranging from 0.6 to $6 \mu \mathrm{m}$ (Soliman, 2011; Rao, 2010; Hardy et al., 2005) which are also smaller than the cell diameters. High-speed micro-particles breach the skin and may penetrate through the individual cell membranes. It is well known that the most recommended material of these micro-particles for gene gun system is gold due to its high density, low toxicity and lack of chemical reactivity (Valenstein, 2012; Rosi et al., 2006; Macklin, 2000). However, tungsten micro-particles have also been used as micro carriers in gene gun systems, due to their lower cost. Tungsten particles have some disadvantages for genetic transformation, such as non-biocompatibility and toxicity (Bastian et al., 2009; Yoshimisu et al., 2009; Russell et al., 1992). Recently, Hou et al. (2013) have used titanium dioxide $\left(\mathrm{TiO}_{2}\right)$ for biolistic micro-particle delivery due to their biocompatibility (Singh and Dahotre, 2007) and low density $\left(2 \mathrm{~g} / \mathrm{cm}^{3}\right)$ which may reduce the cell damage after particle impaction. The particle impaction may cause cell damage (O'Brien and Lummis, 2011; Sato et al., 2000), which is a significant area for gene gun research.

\subsection{Gas pressure and particle velocity}

Up to now, gene gun systems have been widely used to deliver DNA loaded micro-particles into cells for research of DNA transfection, e.g., CST (Rasel et al., 2013; Liu, 2008; Truong et 
320 al., 2006; Liu et al., 2006; Kendall, 2002) and Helios gene gun (O'Brien and Lummis, 2011;

321 Belyantseva, 2009). Helium and compressed air gases are often used as driving forces to 322 accelerate micro-particles for gene gun system. Especially, helium gas is recommended for 323 most gene gun systems due to its non-toxic, low density, lack of chemical inactivity and high 324 compressibility factor (Marrion et al., 2005), which allow the particles to reach higher velocities 325 (Tekeuchi et al., 1992). Compressed air is often used as a substitute for helium due to its lower 326 cost.

328 The gas pressure is a major factor which should be considered for gas gene gun systems. It 329 directly affects the velocity of the micro-particles, e.g., Liu et al. (2008) demonstrated that 1.8 $330 \mu \mathrm{m}$ diameter gold micro-particles can reach a velocity of 580, 650, 685 and 710 at 3, 4, 5 and 6 $331 \mathrm{MPa}$, respectively. In addition, the velocity is also related to the micro-particle size and density: 332 particle velocity is increased from an increase in operating pressure and a decrease in particle 333 size. 
Table 1: Illustration of the particle material and size for the relevant gene gun systems

\begin{tabular}{|c|c|c|c|}
\hline Type of gene gun & $\begin{array}{l}\text { Material of } \\
\text { particles }\end{array}$ & $\begin{array}{l}\text { Average diameter of } \\
\text { micro-particles }(\mu \mathrm{m})\end{array}$ & Reference \\
\hline Powder particle gun (PPG) & Tungsten & 4 & Klein et al. (1987) \\
\hline \multirow[t]{2}{*}{ Helium-driven apparatus (HDA) } & Tungsten & 3.9 & Williams et al. (1991) \\
\hline & Gold & $1-3,3-5$ & \\
\hline Conical nozzle $(\mathrm{CN})$ & Polymeric & $4.7,15.5$ and 26.1 & Quinlan et al. (2001) \\
\hline $\begin{array}{l}\text { Converging-diverging nozzle } \\
\text { (CDN) }\end{array}$ & Polystyrene & 4.7 & Kendall et al. (2004a) \\
\hline \multirow[t]{3}{*}{ Pneumatic gun (PG) } & Gold & $0.47 \pm 0.15,1.1 \pm 0.1$ & Rinberg et al. (2005) \\
\hline & Silicon & $2-18$ & Zilony et al. (2013) \\
\hline & Gold & 1.6 & \\
\hline Light gas gun (LGG) & Stainless steel & 25 & Mitchell et al. (2003) \\
\hline $\begin{array}{l}\text { Contoured shock tube } \\
(\mathrm{CST}) / \mathrm{LGG}\end{array}$ & Polystyrene & $15.5,25.2,48$ and 99 & \\
\hline \multirow[t]{5}{*}{ CST } & Gold & 3.03 & Truong et al. (2006) \\
\hline & Polystyrene & 15 and 48 & \\
\hline & Glass & 46 & \\
\hline & Gold & 2.7 and 3.5 & \\
\hline & Polystyrene & $39 \pm 1$ & Liu et al. (2006) \\
\hline \multirow[t]{2}{*}{ Helios gene gun } & Gold & $0.6,1.0$ and 1.6 & Uchida et al. (2009) \\
\hline & & 1 & $\begin{array}{l}\text { O'Brien and Lummis } \\
\text { (2011); Kuriakose et al. } \\
\text { (2012); } \\
\text { Cao et al. (2013) }\end{array}$ \\
\hline $\begin{array}{l}\text { Biolistic PDS/1000 Helium } \\
\text { system (BioRad, USA) }\end{array}$ & Gold & $0.6,1.0$ and 1.6 & Zuraida et al. (2010) \\
\hline $\begin{array}{l}\text { BioWare low pressure gene } \\
\text { gun }\end{array}$ & Gold & 1 & Yen and Lai (2013) \\
\hline
\end{tabular}


Along with the development of gene gun technology, the achievable particle velocity and penetration depth in the target vary between gene gun systems. For example, Quinlan et al. (2001) have applied a conical nozzle to accelerate polymeric micro-particles of 4.7, 15.5 and $26.1 \mu \mathrm{m}$ diameters, to reach velocities of 350,460 and $465 \mathrm{~m} / \mathrm{s}$ at 60 bar pressure, respectively. A contoured nozzle has been tested by Quinlan et al. (2001) who employed 60 bar to accelerate polymeric micro-particles of $4.7 \mu \mathrm{m}$ diameter to a velocities of about 1000 $\mathrm{m} / \mathrm{s}$, but $26.1 \mu \mathrm{m}$ diameter of particles only reached 740 to $810 \mathrm{~m} / \mathrm{s}$. The velocity of polymeric micro-particles of $15.5 \mu \mathrm{m}$ diameter only reaches $330 \mathrm{~m} / \mathrm{s}$ at 60 bar for the LGG system (Mitchell et al., 2003). Kis et al. (2011) have concluded that the particle velocity reached about $700 \mathrm{~m} / \mathrm{s}$ for CST (Liu et al., 2006) and range from 200 to $800 \mathrm{~m} / \mathrm{s}$ for converging-diverging nozzles (Liu et al., 2004b; Kendall, 2002; Quinlan et al., 2001). Recently, Menezes et al. (2012) have operated an advanced laser plasma jet to drive gold micro-particles of $1 \mu \mathrm{m}$ diameter to achieve an average velocity of $1100 \mathrm{~m} / \mathrm{s}$ within a distance of only $10 \mathrm{~mm}$. The particular achievements (e.g., particle velocity, operating pressure and penetration depth) for various gene gun systems are listed in Table 2.

351 From the above studies, it can be concluded that the operating pressures for gene gun systems generally vary from 20 to 60 bars. Xia et al. (2011) have suggested that the pressure should be held below about 13 bar to minimise damage from the impaction of pressurized gas on soft tissue. Uchida et al. (2009) achieved gene transfection is cells but noted damage if the operating pressure is over 13 bar. These reports demonstrate that cell death is unavoidable for many of the current generation of gene gun systems. Mitchell et al. (2003) show that golden micro-particles of $3.03 \mu \mathrm{m}$ diameter employed at 60 bar pressure in the CST only reach a maximum penetration depth of $60 \mu \mathrm{m}$ in the canine buccal mucosa. Normally, the viable epidermis layer of skin is the target area for gene gun systems. Mitchell et al.'s (2003) results show that micro-particles require a still higher velocity to penetrate through the stratum 361 corneum, which means higher operating pressures are necessary. However, Mitchell et al. 362 (2003) also show stainless steel micro-particles of $25 \mu \mathrm{m}$ diameter can achieve $124 \mu \mathrm{m}$ penetration depths in the canine buccal mucosa at 20 bar pressure (see Table 2). But O'Brien and Lummis (2011) show that cultured cells are damaged by gold micro-particle of $1 \mu \mathrm{m}$ diameter, when operating at 3.4 bar pressure using a Helios gene gun. They indicate that 
367 will damage the target tissue and cells. Thus, a new concept of applying $\mathrm{MN}$ to micro-particle

368 delivery, which may reduce the cell damage, is discussed in section 4.2.

Table 2: Illustration of the materials and size of micro-particles used in gene gun systems

\begin{tabular}{|c|c|c|c|c|c|}
\hline $\begin{array}{l}\text { Gene } \\
\text { gun }\end{array}$ & $\begin{array}{l}\text { Material and } \\
\text { average diameter } \\
\text { of micro-particles }\end{array}$ & $\begin{array}{l}\text { Operating } \\
\text { pressure } \\
\text { (bar) }\end{array}$ & $\begin{array}{l}\text { Velocity } \\
\text { at impact } \\
(\mathrm{m} / \mathrm{s})\end{array}$ & $\begin{array}{l}\text { Target and } \\
\text { maximum } \\
\text { Penetration } \\
\text { depth in target }\end{array}$ & Reference \\
\hline PPG & Tungsten, $\quad 4 \mu \mathrm{m}$ & N/A & 430 & Onion, $40 \mu \mathrm{m}$ & Klein et al. (1987) \\
\hline HAD & Gold, 1 - $3 \mu \mathrm{m}$ & 90 & $\mathrm{~N} / \mathrm{A}$ & $\begin{array}{l}\text { Mouse liver } \\
\text { tissue, } \sim 130 \mu \mathrm{m}\end{array}$ & $\begin{array}{l}\text { Williams et al. } \\
\text { (1991) }\end{array}$ \\
\hline $\mathrm{CN}$ & $\begin{array}{l}\text { Polymers, } 4.7,15.5 \\
\text { and } 26.1 \mu \mathrm{m}\end{array}$ & 60 & $\begin{array}{l}350, \quad 460 \\
\text { and } 465\end{array}$ & $N / A$ & $\begin{array}{l}\text { Quinlan et al. } \\
(2001)\end{array}$ \\
\hline LGG & $\begin{array}{l}\text { Stainless steel, } 25 \\
\mu \mathrm{m}\end{array}$ & 20 & 170 & $\begin{array}{l}\text { Canine buccal } \\
\text { mucosa, } 124 \mu \mathrm{m}\end{array}$ & $\begin{array}{l}\text { Mitchell et al. } \\
(2003)\end{array}$ \\
\hline CST & Gold, $3.03 \mu \mathrm{m}$ & 60 & 550 & $\begin{array}{l}\text { Canine buccal } \\
\text { mucosa, } 60 \mu \mathrm{m}\end{array}$ & \\
\hline CST & Gold, $1 \pm 0.2 \mu \mathrm{m}$ & 40 & 580 & $\begin{array}{l}\text { Human skin, } 66 \\
\mu \mathrm{m}\end{array}$ & Kendall (2002) \\
\hline CST & $\begin{array}{l}\text { Polystyrene, } \quad 39 \\
\mu \mathrm{m}\end{array}$ & 60 & $\begin{array}{l}570 \\
14.7\end{array}$ & $\mathrm{~N} / \mathrm{A}$ & Liu et al. (2006) \\
\hline $\begin{array}{l}\text { Helios } \\
\text { Gene } \\
\text { Gun }\end{array}$ & $\begin{array}{l}\text { Gold, } 40 \mathrm{~nm} \text { and } \\
1 \mu \mathrm{m}\end{array}$ & 5 & $\mathrm{~N} / \mathrm{A}$ & $\begin{array}{l}\text { Mouse } \\
\text { tissue, } 50 \pm 11 \\
\mu \mathrm{m} \text { and } 31 \pm 6 \\
\mu \mathrm{m}\end{array}$ & $\begin{array}{l}\text { O'Brien and } \\
\text { Lummis (2011) }\end{array}$ \\
\hline $\begin{array}{l}\text { Laser } \\
\text { plasma } \\
\text { jet }\end{array}$ & $\begin{array}{l}\text { Gold, } 1 \mu \mathrm{m} ; \\
\text { Tungsten, } 1 \mu \mathrm{m}\end{array}$ & N/A & 1100 & N/A & $\begin{array}{l}\text { Menezes et al. } \\
(2012)\end{array}$ \\
\hline
\end{tabular}




\section{MNs}

\subsection{Types and configurations of MNs}

Henry et al. (1998) are widely regarded as the first to have developed a method of transdermal drug delivery using MNs, which has gradually developed for various applications of drug delivery. MN arrays are minimally invasive device that bypass the outer layer of skin, namely the stratum corneum, to achieve enhanced transdermal drug delivery (Olatunji et al., 2013; Donnelly et al., 2012; Prausnitz and Langer, 2008). MN are normally separated into two categories, namely, solid and hollow (Koelmans et al., 2013; Han et al., 2008; Qi et al., 2007). Each of these can be made of different materials and used for various functionalities, depending on their designs. The most common materials used for fabricating MN are metal, silicon, and polymer (Kim et al., 2012; Memon et al., 2011; Zhao et al., 2006). The primary metals used for MNs are stainless steel (Kim et al., 2012; Quan et al., 2010; Bal et al., 2008; Martanto et al., 2004) and titanium (Kim et al., 2010; Fermandez et al., 2009; Parker et al., 2007). Metal MNs have the advantages of low cost, tougher hardness, ease of penetration into the tissue and they are not easily broken in the tissue. Silicon and silica materials have better biocompatibility than metallic materials, but they are expensive (Chen et al., 2013, 2008). Furthermore, they break up more easily and fragments may be left inside the tissue after MN removal (Memon et al., 2011; Zhao et al., 2006). However, silicon is the first material used to fabricate MNs for pre-treatment of skin prior to patch application, e.g., Henry et al. (1998) have used solid conical silicon MNs (Figure 14a) with a height of $0.15 \mathrm{~mm}$, inner diameter of $80 \mu \mathrm{m}$ and tip diameter of $1 \mu \mathrm{m}$ to increase skin permeability and to provide an effective delivery of drugs to diffuse through the skin. Mikszta et al. (2002) used a silicon MN array (see Figure 14b) for gene delivery in skin.

Polymeric materials are a cheap option which can exhibit biocompatibility and biodegradability, but the hardness is generally lower (Nayak and Das, 2013; Oh et al., 2008; Han et al., 2007; Park et al., 2005). Various types of polymer have been used for fabricating MNs, such as poly-glycolic acid (PGA) (Park et al., 2006, 2005) and polycarbonate (PC) (Han et al., 2007).

401 Park et al. (2005) have fabricated a PGA solid MN array with needle length of $1500 \mu \mathrm{m}$, base diameter of $200 \mu \mathrm{m}$ tapering to tip diameter of $20 \mu \mathrm{m}$. An example of solid polymer MN array is shown in Figure 15a. Recently, Donnelly et al. (2011) have used poly (vinyl) alcohol (PVA) to 
404

405

406

407

408

409

410

411

412

(b)

(a)

(a)

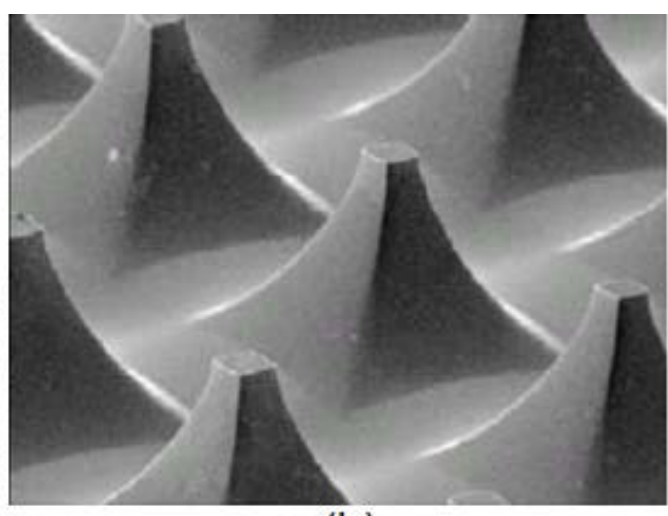

(b)

Figure 14: (a). Solid conical MN arrays (Henry et al., 1998) (b) Silicon MN array used for gene delivery in skin (Mikszta et al., 2002).
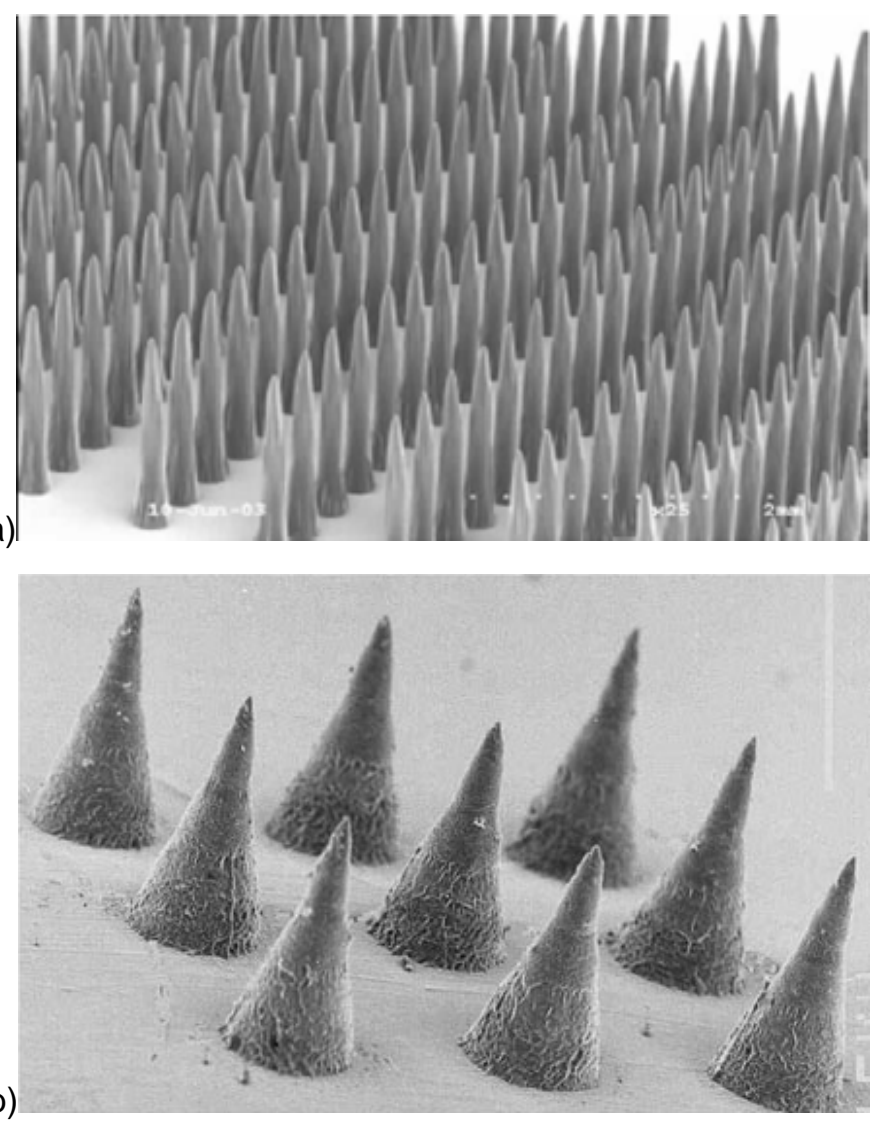

415 array made with the help of PVA (Donnelly et al., 2011) 
417 Hollow MN arrays are normally used for fluid infusion of liquid drug and nanoparticles into the 418 skin (Han et al., 2008). However, they are not widely used due to their cost and complex 419 fabrication methods (Zhu et al., 2012). An example of the hollow MN array designed by 420 Stoeber and Liepmann (2000) is shown in Figure 16a. It is a hollow conical MN array with a 421 height of $200 \mu \mathrm{m}$ and a channel diameter of $40 \mu \mathrm{m}$. McAllister et al. (2000) have improved 422 Henry et al.'s (1998) design, by inserting a hole in the centre of each MN to fabricate a hollow 423 silicon MN array.

424

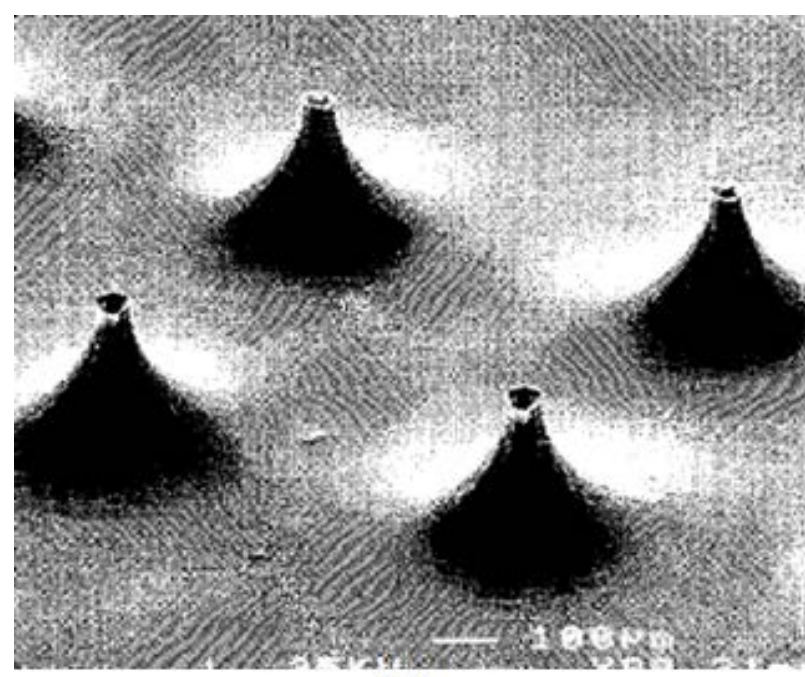

(a)

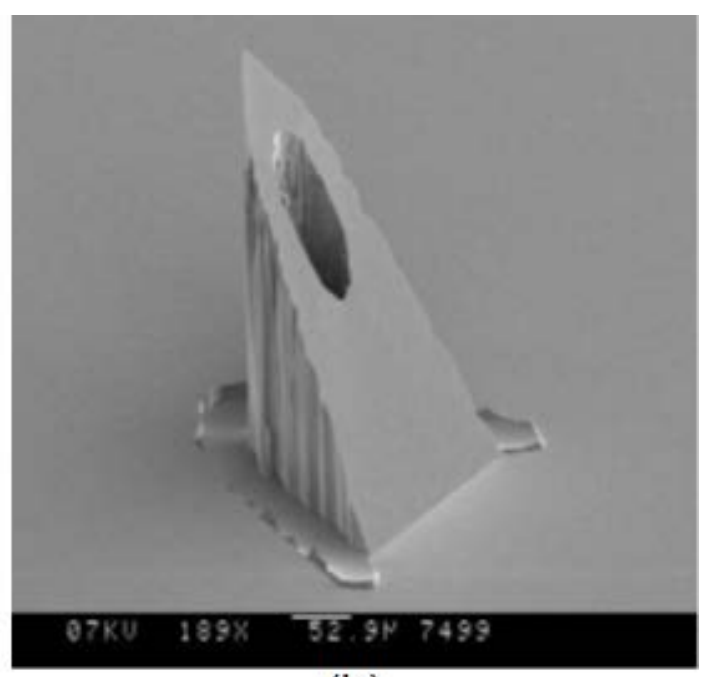

(b)
425

426

427

428

429

430

431

432

433

434

435

436

Figure 16: (a) Hollow conical MN arrays on the right (Stoeber and Liepmann, 2000) (b) hollow silicon MN array with sloping side walls (Gardenier et al., 2003)

Subsequently, Gardenier et al. (2003) have designed a hollow silicon MN array with sloping side wall, which is shown in Figure 16b. The length of the needles varies between 150 and 350 $\mu \mathrm{m}$, with a base diameter of $250 \mu \mathrm{m}$ (measured at the widest section) and a maximum hole width of $70 \mu \mathrm{m}$. The centre of the hole is positioned $40 \mu \mathrm{m}$ from the tip of the needle. Davis et al. (2004) have used a hollow metal MN array (Figure 17) with a tip diameter of $75 \mu \mathrm{m}$, base diameter of $300 \mu \mathrm{m}$, wall thicknesses of $5 \mu \mathrm{m}$ and height of $500 \mu \mathrm{m}$ to measure the required force for the insertion of MNs into the tissue. They reported that a force ranging between approximately $0.1-3 \mathrm{~N}$ is sufficient to penetrate a single $\mathrm{MN}$ into the tissue. 


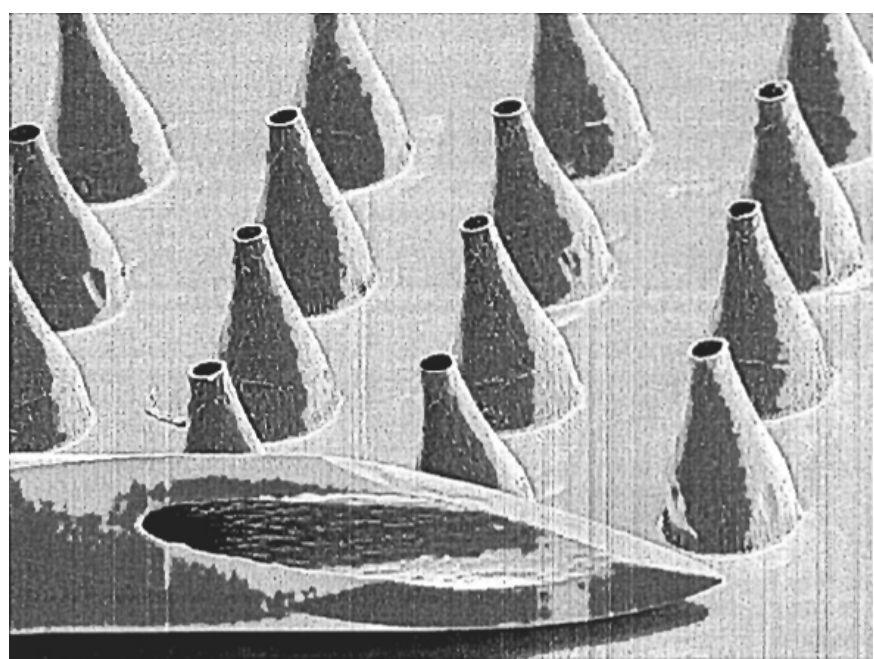

Figure 17: Hollow metal MNs (Davis et al., 2004)

Until now MNs have been developed as a minimally invasive means to deliver genes via the transdermal route (Tuan-Mahmood et al., 2013; Coulman et al., 2009; Henry et al., 1998), e.g.,

441 Chabrai et al. (2004) have successfully used micro-fabricated silicon MNs for non-viral gene delivery without causing pain. Recently, Zhang et al. (2013) have proposed the use MNs with a gene gun system to assist the micro-particle delivery in the skin. In particular, solid MNs can create holes in the tissue to provide an environment for the penetration of high-speed micro-particles. Furthermore, hollow MNs may allow a number of micro-particles to go through the hollow needles and penetrate to a greater depth into deeper tissue layers to be gene transfected. However, the waste of micro-particles is likely to be higher as the hollow MNs have blockage problems.

There have been a number of studies which report on the effects of MNs types and configuration on drug delivery (Han and Das, 2013; Olatunji et al., 2012; Al-Qallaf and Das, 2009a,b, 2008; Al-Qallaf et al., 2009a,b, 2007; Davidson et al., 2008). The current contribution will focus on the most relevant MNs types and configurations; reviews of other aspects related

454 to the application of MN may be found elsewhere (Olatunji and Das, 2011, 2010).

\subsection{MN insertion in skin}

457 MNs can overcome a target surface to provide an advantageous condition for micro-particle 458 delivery (Zhang et al., 2013). Human skin consists of two distinct macroscopic layers called the dermis and the epidermis (Marks et al., 2006; Parker, 1991; Phipps, 1988) which are shown in 
Figure 18. The epidermis layer consists of the stratum corneum (SC), the stratum basale (or

461 stratum germinativum), stratum sinosum, and the stratum granulosum (Gerard et al., 2011; Marks et al., 2006; Holbrook, 1994). The top layer of the skin is the SC which is the major barrier for entry of foreign substances. The thickness of the epidermis varies with gender, age, ethnicity and the regions of the body, but has an average thickness of between 20 and $100 \mu \mathrm{m}$ (Matteucci et al., 2009; Schaefer and Redelmeier, 1996). The thickness of the stratum corneum also varies with the above conditions, but the average thickness is between 10 and $20 \mu \mathrm{m}$ (Mohammed et al., 2012; Holbrook et al., 1974).

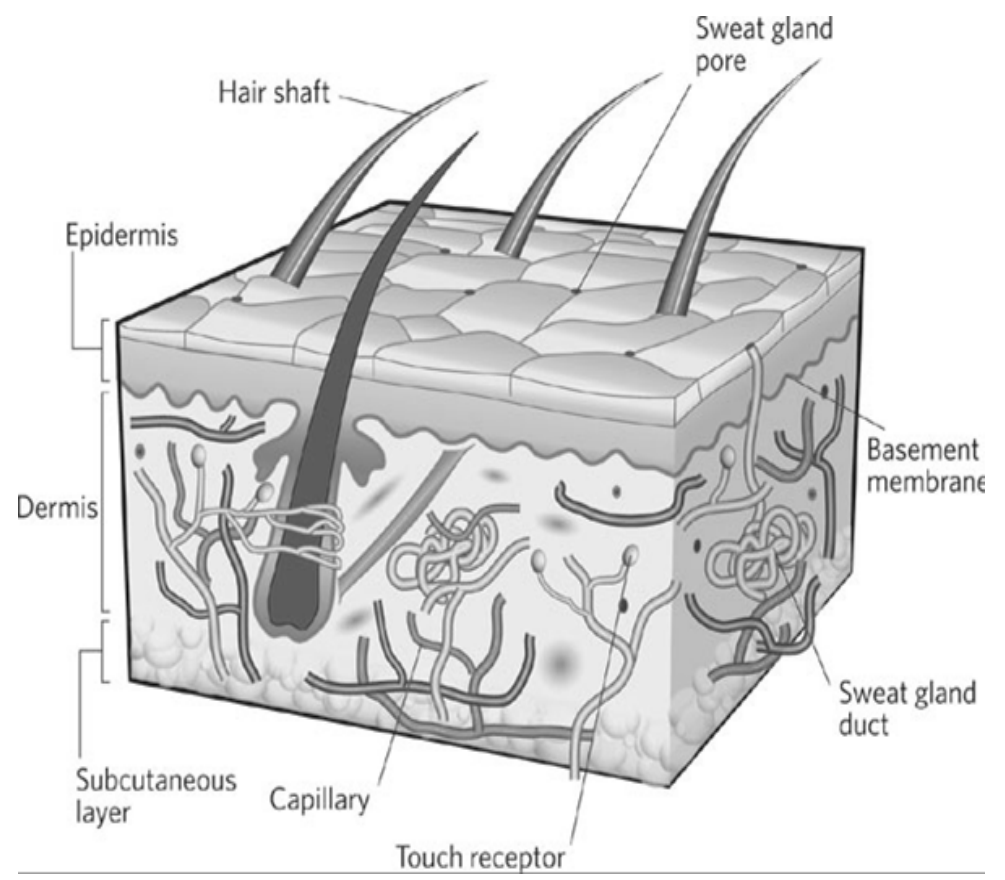

Figure 18: The structure of the skin (MacNeil, 2007)

472 Normally, MN insertion is painless as it simply penetrates the skin surface without reaching the dermis layer, which contains the nerves ending. (Gupta et al., 2011a; Silpi et al., 2011; 474 Donnelly et al., 2010a; Henry et al., 1998). Pain sensation depends on the MN design which is generally small enough to avoid significant damage to the nerves in the tissue (Shah et al., 2011; Palastanga et al., 2006; Kaushik et al., 2001). Also, as the pain sensation is related to

477 the MN design, an increased size increases the likelihood of stimulating the nerves (Sachdeva and Banga, 2011; Shah et al., 2011; Gupta et al., 2011a,b). There are a number of clinical studies which show that MNs insertions into skin are painless, or the pain is undetectable. For example, Mikolajewska et al. (2010) have used polymeric MN cones with needle height of 644 
$\mu \mathrm{m}$, base diameter of $217 \mu \mathrm{m}$ tapering to tip diameter of $41 \mu \mathrm{m}$ to progress the skin 482 pre-treatment and report that the MNs insertion is a painless process. Previously, Haq et al. 483 (2009) have used several MN arrays with lengths of 180 and $280 \mu \mathrm{m}$ and compared the pain 484 responses of a number of subjects for these MNs with the pain responses from hypodermic needles. They indicated that a hypodermic needle is painful after insertion into skin, and the pain response of MN insertion is less and decreases with a decrease in needle height.

The irregular surfaces and viscoelasticity of skin causes difficulty with MN insertion. In addition, the skin is generally folded after the insertion of MNs, which may cause MNs to pierce partially, depending on the MN length (Verbaan et al., 2008). Thus, there is a need to understand the required force to insert a given MNs in the skin; the depth of MN penetration into the skin is directly related to the used force for penetration (Olatunji et al., 2013; Donnelly et al., 2010b). In addition, the depth of MN penetration in the skin is dependent on the length of MNs (Badran et al., 2009).

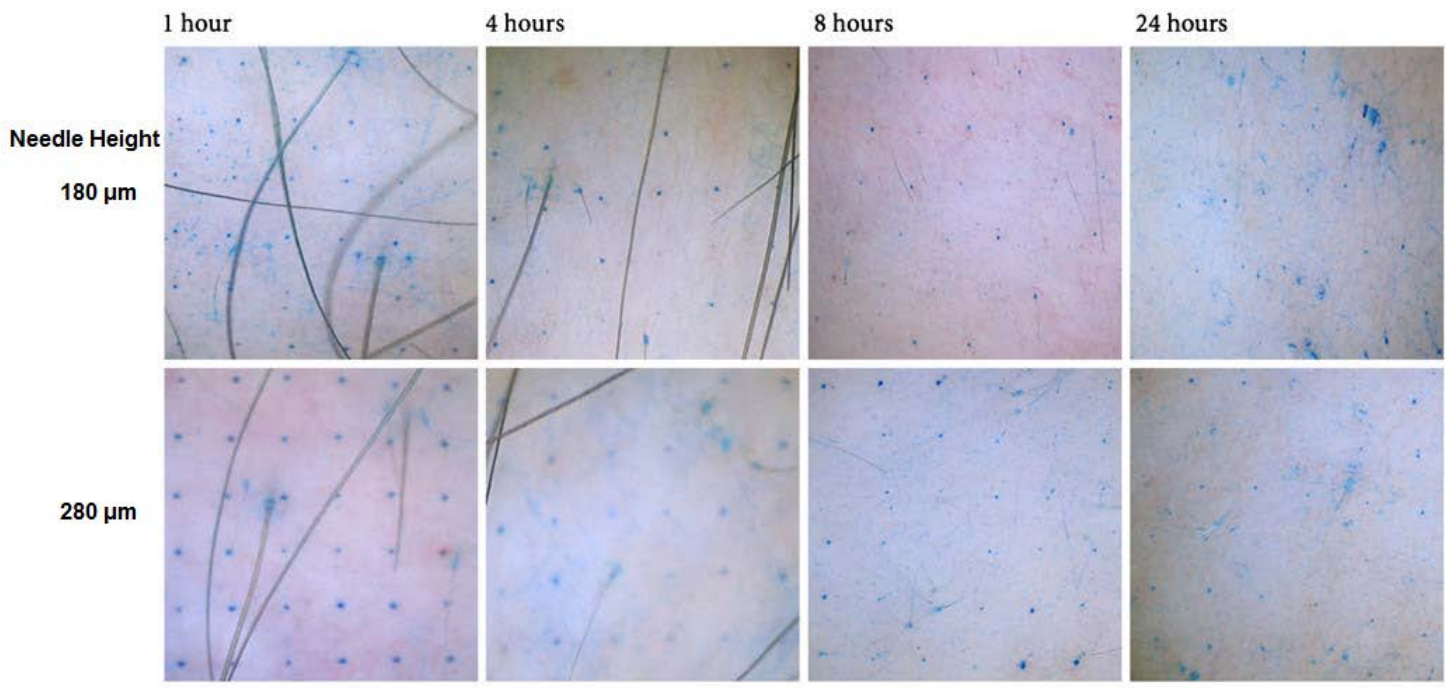

Figure 19: Methylene blue staining of MN holes on the human skin (needle height: 180 and $280 \mu \mathrm{m})($ Haq et al., 2009)

Several studies of MN insertion in skin show that the holes remain in the skin after the removal of the MNs (e.g., Haq et al., 2009), as shown in Figure 19. Previously, McAllister et al. (2003)

501 have applied a cylindrical MN of $20 \mu \mathrm{m}$ diameter to perform staining experiments, which 502 indicates that a hole will remain after the removal of MNs. Martanto et al. (2004) have shown that a number of visible holes remained when MNs were applied with needle lengths of 1000 
$504 \mu \mathrm{m}$ and width of $200 \mu \mathrm{m}$ by $50 \mu \mathrm{m}$ on a rat skin. In addition, McAllister et al. (2003) have

505 reported a residual MN hole of radius $6 \mu \mathrm{m}$ following insertion of MNs with radius of $10 \mu \mathrm{m}$,

506 which means that the holes shrink to $\sim 60$ percent of the diameter of the MNs. While inserting

507 the MNs, it can also be seen that the entire MN length cannot be inserted into the skin

508 completely, and the depth of penentration of $\mathrm{MN}$ in skin is related to its length and the

509 application force. These factors directly affect the size of pierced holes before and after the

510 removal of MNs, Donnelly et al. (2010b) have used optical coherence tomography (OCT) to

511 detect the effect of MN height and application force on the depth of penentration inside the

512 porcine skin. As shown in Figure 20a, the penetration depth is increased significantly by an

513 increase in MN height and application force. In addition, the application force presents a

514 positive effect on the penetration depth of the MN inside skin, as shown in Figure 20b: the pore

515 width is increased by an increase in needle height and application force, when the base width

516 is kept constant. However, there is a clear gap left between the MN base plate and the skin

517 surface. Donnelly et al. (2011) have further used OCT to obtain 3D views of MN embedded in

518 the human skin. They reported that a MN with needle height of $600 \mu \mathrm{m}$ and base diameter of

$519300 \mu \mathrm{m}$ penetrated approximately $460 \mu \mathrm{m}$ into the human skin with a clear gap of $136 \mu \mathrm{m}$

520 between the MN base plate and skin. They also indicated that the width of the pierced holes in

521 the skin was about $265 \mu \mathrm{m}$ in diameter. These reports demonstrate that MN assisted

522 micro-particle delivery is expected to realize a greater penetration depth of micro-particles in

523 the skin.

524

525 4. Potential of MN assisted micro-particle delivery

\section{$526 \quad 4.1$ MN assisted micro-particle delivery}

527 As mentioned earlier, cell and tissue damages are particular problems for the biolistic gene

528 transfection (Obrien et al., 2011; Uchida et al., 2009; Thomas et al., 2001; Sato et al., 2000;

529 Yoshida et al., 1997). Reduction in the operation pressure and in the particle size can minimize

530 the cell damage, but these also decrease the momentum of the micro-particles. This

531 minimizes the penetration depth of the micro-particles in the tissue and may cause a failure of

532 the DNA transfection.

533 
(a)
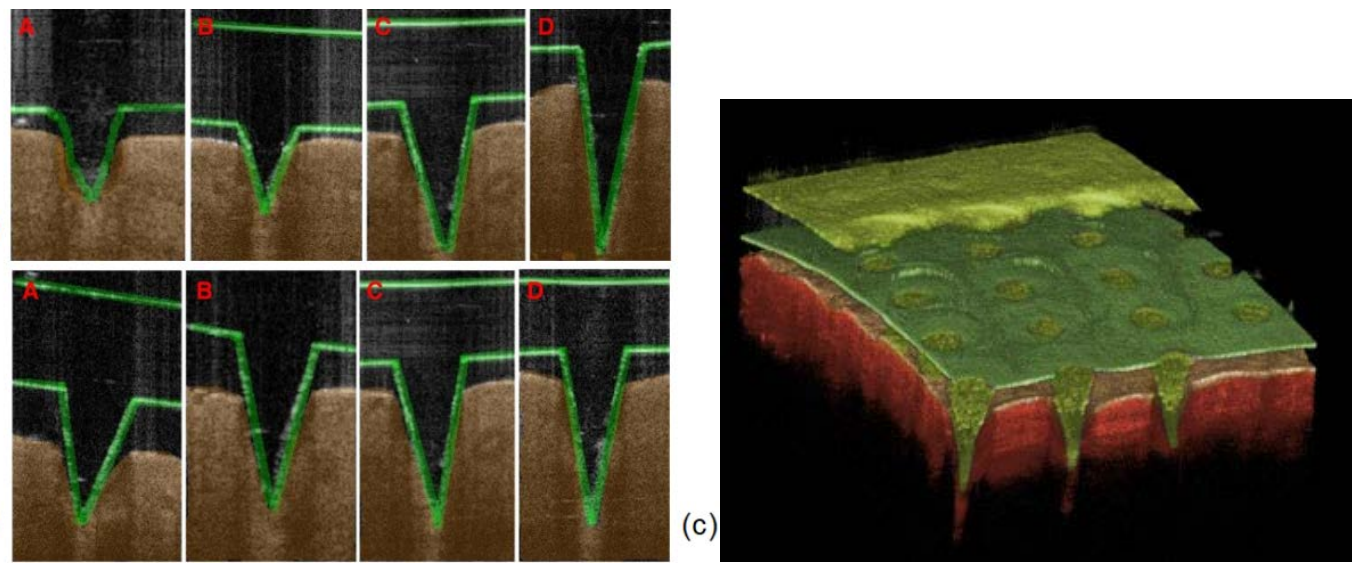

Figure 20: (a): A 2D OCT image for the investigation of the effect of the MN height on the penetration depth inside the porcine skin (A: $280 \mu \mathrm{m}$; B: $350 \mu \mathrm{m}$; C: $600 \mu \mathrm{m}$; D: $900 \mu \mathrm{m}$ ) (Donnelly et al., 2010b) (b): A 2D OCT image to analyse the effect of the application force on the penetration depth of $M N$ inside the porcine skin (A: $4.4 \mathrm{~N} ; B: 7.0 \mathrm{~N} ; \mathrm{C}: 11 \mathrm{~N} ; \mathrm{D}: 16.4 \mathrm{~N}$ ) (Donnelly et al., 2010b) (c): A 3D OCT image showing MN insertion in the skin (needle height: $600 \mu \mathrm{m}$; base width: $300 \mu \mathrm{m}$; spacing: $300 \mu \mathrm{m}$ ) (Donnelly et al., 2011).

Based on a consideration of reducing the operating pressure, a new concept of combining MNs with gene guns for micro-particle delivery has been presented by Zhang et al (2013). As presented in Figure 21, the concept may be developed from the light and Helios gas gun systems. The operating process consists of particle acceleration, separation and deceleration stages. For the acceleration stage, a pellet of micro-particles is loaded onto the ground slide which is accelerated by pressurized gas. The pellet is then separated into individual micro-particles by impaction onto a mesh stopping screen in the separation stage. The separated micro-particles spray forward through a conical nozzle with a uniform velocity and distribution to breach the skin tissue to target the cells of interest.

As shown by Zhang et al (2013), by using an array of MNs it is possible to overcome the effect of the skin on the particle penetration. One of the many advantages of this new concept is that the pressurized gas will be released from the vent holes (see Figure 21), which is likely to avoid the damage of the target from the impaction of pressurized gas on tissue. In addition, the use of the ground slide slows down the velocities of micro-particles to reduce the impact force on tissue to minimize the cell damage. As required, the velocity is controllable by changing the driving pressure of compressed gas, if higher micro-particle velocities are necessary. Even if the micro-particles cannot reach the desired penetration depth due to insufficient momentum, 
561 of gene transfection in the desired depth of the tissue. However, the disadvantage of this concept is that a very high impact velocity of micro-particles is not easy to achieve, because

563 the ground slide has significant mass.

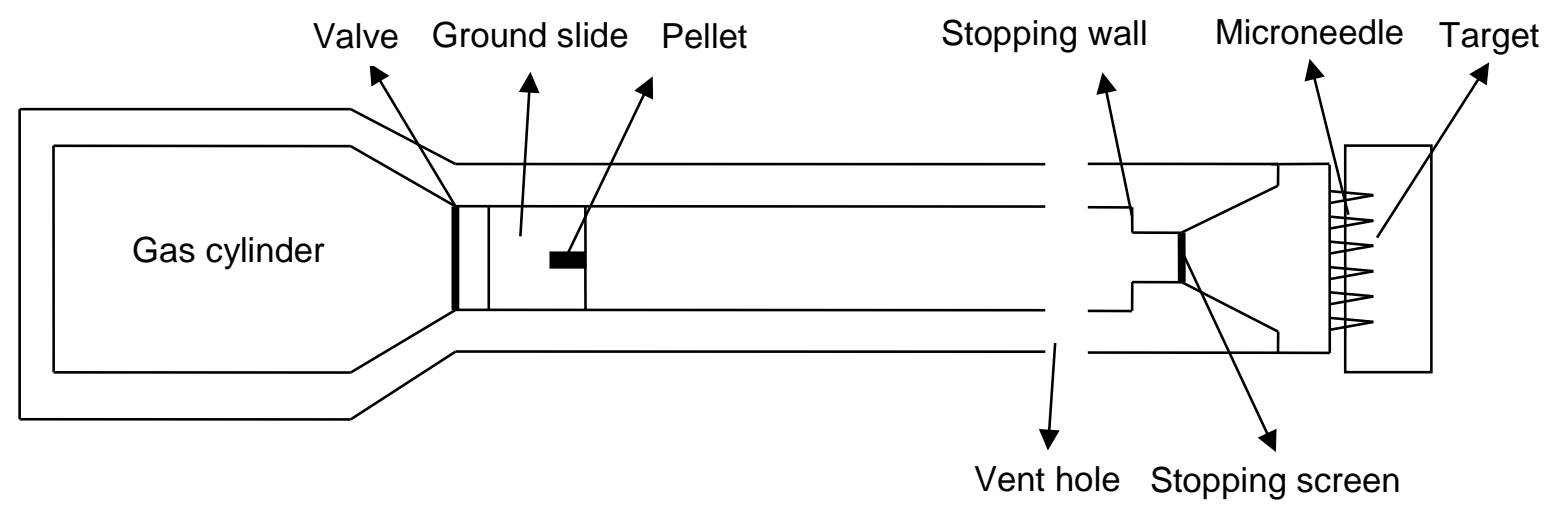

564

565

566

567 The solid MN used by Zhang et al. (2013) aimed to create holes on the skin to allow a number

568 of micro-particles penetrate through the pierced holes and increase the penetration depth.

569 Zhang et al. (2013) also indicate that some agglomerated micro-particle may be present in the 570 target; the size of the agglomerates is controllable and decreases with a decrease in mesh

571 size and binder concentration. Results (see Figure 22) have shown that a number of 572 micro-particles are able to penetrate through the pierced holes (created by the MNs) and

573 reached a greater penetration depth inside the target, demonstrating the feasibility of MN

574 assisted micro-particle delivery. In principle, the maximum penetration depth of micro-particles

575 is affected by the particle size, density and operating pressure which determine the 576 momentum of the micro-particles and hence the impact of the particles on the target. An 577 increased length of the pierced holes enhances the particle penetration depth due to a decreased resistance when micro-particle travel in the hole. The length of the pierced holes depends on the height of MN. 
582

583

584

585

586

587

588

589

590

591

592

593

594

595

596 damage to the skin. gel (Zhang et al., 2013)

Figure 22: Optical microscope image of stainless steel micro-particle penetration into agarose

\subsection{Effects of physical approaches to drug delivery}

With the development of transdermal drug delivery, several physical technologies have been developed, particularly in needle free gene gun systems. In order to understand the advantages of MN assisted micro-particle delivery for the drug/gene delivery, a comparison with other physical cell targeting approaches is presented in this section. Figure 23 illustrates a schematic of four physical cell targeting approaches, which include diffusional delivery (Figure 23a), solid MN assisted micro-particle delivery (Figure 23b), hollow MN assisted micro-particle delivery (Figure 23c) and needle free biolistic micro-particle injection (Figure 23d). The route of the diffusion delivery (Figure 23a) is that the molecules permeates through the aperture of the SC and diffuse into the target (Glenn et al., 2003). It is a method which operates without

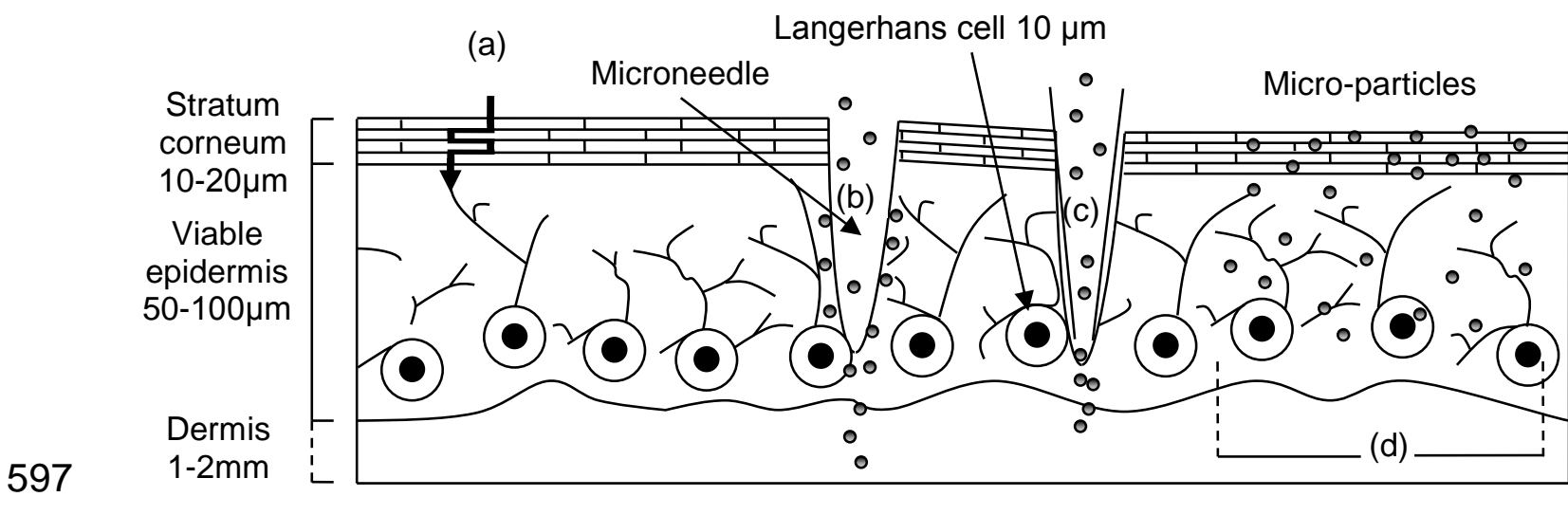

598 Figure 23: A schematic cross-section of the skin: (a) the normally diffusion route (b)route of 599 solid MN assisted micro-particle delivery (c) route of hollow MN assisted micro-particle delivery 600 (d) route of normal micro-particle penetration using a gene gun system (Kendall, 2006) In recent years, needle-free biolistic micro-particle delivery (Figure 23d) provides a great improvement for transdermal gene delivery. The principle of this technique is that DNA is 
604 loaded onto micro-particles which are accelerated to a sufficient velocity to pierce the skin and

605 travel to a certain depth to achieve the DNA transfection in the viable epidermis layer. It can be 606 seen from Figure 23d that micro-particles penetrate to greater depth than diffusion delivery. In

607 addition, biolistic micro-particle delivery is painless as the micro-particles settle within

608 epidermis without reaching the nerves (Quinlan et al., 2001). There are some disadvantages

609 for biolistic micro-particle delivery such as micro-particle penetration causes a significant cell

610 death in the skin due to impaction (O'Brien and Lummis, 2011; Raju et al., 2006; Sato et al.,

611 2000). In addition, pressurized gas may damage the skin surface, if the pressure is over than

612200 psi (Belyantseva, 2009; Uchida et al., 2009; Yoshida et al., 1997).

614 As mentioned earlier, the method of MN assisted micro-particle delivery requires use of a MN

615 to overcome the skin surface to deliver micro-particles to a greater depth. The projected routes

616 are presented in Figure 23b-c. In Figure 23b the penetration depths of micro-particles are

617 greater than for needle-free biolistic micro-particle delivery, due to the pierced holes providing

618 a low resistance path for micro-particle penetration. Figure 23c shows hollow MN assisted

619 micro-particle delivery, which should allow particles to penetrate further in the skin via the

620 hollow needles. However, the disadvantage of MN assisted micro-particle delivery is that the

621 process may be painful if the micro-particles are deliver into dermis which have nerves ending

622 in that layer.

623

624 Overall, it is obvious that needle-free biolistic micro-particle injection present more efficiency 625 than diffusion delivery. Ziegler (2008) has shown that acceptable DNA vaccination requires the 626 coated micro-particle to penetrate the skin surface with around 20-100 $\mu \mathrm{m}$ penetration depth. It 627 indicated that needle-free biolistic micro-particle injection achieves a more efficient 628 pharmaceutical effect than diffusion delivery. Further, MN assisted micro-particle delivery may 629 deliver micro-particles deeper than the needle-free gene gun system in the skin to allow 630 deeper tissues to be transfected. This it has been demonstrated that $\mathrm{MN}$ assisted 631 micro-particle delivery may achieve a further enhanced DNA transfection in the target. 
634 The process of micro-particle delivery is normally divided into two stages, which are the particle acceleration and penetration stages. In the modelling, the acceleration stage should

636 be considered along with the driving source (gas pressure) which accelerates the 637 micro-particle to a sufficient velocity to pierce the skin surface. The velocity varies with the 638 gene gun system design, particle density and size. For the penetration stage, the effect of the 639 skin is the major resistance to prevent the micro-particle delivery. Micro-particle delivery 640 requires breaching of the SC and piercing into the epidermis layer (Yager et al., 2013; Soliman

641 et al., 2011b; Liu, 2006; Quinlan et al., 2001; Bennett et al., 1999; Trainer and Alexander, 642 1997). The impact velocity, particle size and density, target density and yield stress are the 643 major variables affecting the penetration depth.

645 Normally, the micro-particle acceleration stage involves gas and particle flow for gas gene gun 646 systems, e.g., CST, PowderJect and Helios Gene gun. The flow is defined as symmetric and 647 fully turbulent in the device (Liu, 2006; Soliman et al., 2011a). A model which has been widely 648 adopted to model micro-particle flow is based on a balance of forces using Newton's second 649 law and Stokes' law. For example, Liu (2006) has focused on simulating the velocity 650 distribution in the converging (conical) section of a venturi system which is developed from a 651 gene gun, namely, the PowderJect system (PowderJect Research Ltd., Oxford, UK) 652 (Bellhouse et al., 1999, 2003, 2006). The particle velocity has been simulated based on a 653 balance between the inertia of micro-particles and other resistance forces acting on the 654 particles. Zhang et al. (2007) have used the MATrix LABoratory (MATLAB, The MathWorks 655 Inc., Natick, USA) (Shampine et al., 1997) to simulate three different stages of the particle 656 delivery in the gene gun, namely, acceleration, separation and deceleration stages. In their 657 work, the particle velocity is analyzed on the basis of Newton's second law in the acceleration 658 stage; an energy conservation law is applied to describe the separation of micro-carriers into 659 micro-particles in the separation stage, and Stokes' law is applied to model the penetration of 660 micro-particles in the deceleration stage into a viscous target. Soliman et al. (2011b) have 661 used a commercial turbo-machinery flow simulator, namely, FINE ${ }^{\mathrm{TM}} /$ Turbo (NUMECA 662 International, Brussel, Belgium) to simulate the behaviour of gas and particle flow in a 663 supersonic core jet in a gene gun. This work used Newton's second law to mimic the particle 
665 below, a number of studies have shown that the penetration depth depends on the momentum of micro-particles which again depend on the particle size, density and velocity.

668 For the penetration stage, various studies have separated the resistance force on the micro-particle into a yield force $\left(F_{y}\right)$, frictional resistive force $\left(F_{f}\right)$ and resistive inertial force of 670 the target material $\left(F_{i}\right)$ (Soliman et al., 2011b; Liu, 2007; Mitchell et al., 2003; Kendall et al.,

671 2001; Dehn, 1987). The force balance equation is shown below:

$$
\mathrm{m} \frac{\mathrm{dv}}{\mathrm{dt}}=-\left(\mathrm{F}_{\mathrm{i}}+\mathrm{F}_{\mathrm{f}}+\mathrm{F}_{\mathrm{y}}\right)
$$

From this the stopping distance can be calculated as

$$
\mathrm{d}=\frac{4 \rho_{\mathrm{p}} \mathrm{r}_{\mathrm{p}}}{3 \rho_{\mathrm{t}}}\left\{\ln \left(\frac{1}{2} \rho_{\mathrm{t}} \mathrm{v}_{\mathrm{i}}^{2}+3 \sigma_{\mathrm{y}}\right)-\ln \left(3 \sigma_{\mathrm{y}}\right)\right\}
$$

675 Based on this force balance equation, the theoretical penetration depth (equation 2) is 676 obtained and adopted for the modelling. This model has been widely adopted in several 677 studies. For example, Soliman et al. (2011b) have modelled the delivery of golden particle of diameters 1.8 and $5 \mu \mathrm{m}$ using $3 \mathrm{MPa}$ pressure and have shown that penetration depths of $95 \mu \mathrm{m}$ and $135 \mu \mathrm{m}$ can be achieved for particle of diameters 1.8 and $5 \mu \mathrm{m}$, respectively.

680 Kendall et al. (2001) have analysed the golden particle penetration by using equation 2 for particle penetration in human and porcine skins. In addition, predictions from the theoretical model have been shown to agree well with the experimental results by Kendall et al. (2001). More recently, Soliman et al. (2011b) have also implemented equation 2 in a theoretical model which is implemented using FINE/Turbo code to calculate the penetration depth of gold micro-particle inside the skin.

\section{Conclusion}

688 The background of the gene gun system for micro-particle delivery is reviewed in this paper. A

689 number of gene gun systems have been listed and the operating principles along with their advantages and disadvantages have been studied briefly. In addition, the recommended gas

691 type, particle material and size for these type engineering systems are discussed. The range 692 of particle velocities and applied operating pressures for several gene gun systems are described, which indicated that cell/tissue damage is a major problem for biolistic 
694 micro-particle delivery, due to the impaction of pressurized gas and high-speed micro-particles

695 on the target tissue. In addressing this point, a new concept is proposed of MN assisted micro-particle delivery, which combines a gene gun system with MN to enhance the

697 penetration depth of micro-particles. This technique may reduce the cell damage from 698 pressurized gas and reduce the impact velocity of micro-particle. In order to further understand the MN assisted micro-particle delivery, a number of MN designs have been discussed, paying attention to key characteristics that affect biolistic delivery.

A number of researchers have studied the MN insertion in the skin which suggests that holes remained on the skin after the removal of MNs. These indirectly show the feasibility of the MN assisted micro-particle delivery to enhance the penetration depths of micro-particles inside the target. Based on the above research works, the detailed penetration route of $\mathrm{MN}$ assisted micro-particle delivery is also discussed and compared with other physical approaches on drug delivery. Finally, various models of micro-particle delivery for different gene gun systems are described to understand the theoretical principles of micro-particle penetration and which may be used for modelling of MN assisted micro-particle delivery.

\section{6. Conflict of Interest}

712 Authors declare no conflict of interest

\section{7. References}

715 Ahlen G., Sallberg M., Frelin L., (2013). Methods for monitoring gene gun-induced HBV- and HCV-specific immune responses in mouse models, Methods Mol. Biol., 940: 239-267

718 Al-Qallaf B. and Das D.B., (2009a). Optimizing microneedle arrays for transdermal drug 719 delivery: Extension to non-square distribution of microneedles, Journal of Drug Targetting, 17(2), pp.108-122, DOI: 10.1080/10611860802472370. 
727 Microneedles: Geometry Effects on Drug Concentration in Blood, Asia-Pacific Journal of 728 Chemical Engineering, 4(6): 845-857, DOI: 10.1002/apj.353. Engineering, 7: A69.1-A69.23.

734 Al-Qallaf B. and Das D.B., (2008). Optimization of square microneedle arrays for increasing 735 drug permeability in skin, Chemical Engineering Science, 63: 2523-2535, DOI: 736 10.1016/j.ces.2008.02.007.

Al-Qallaf B., Das D.B., Mori D., Cui Z.F., (2007). Modelling transdermal delivery of high molecular weight drugs from microneedle systems, Philosophical Transactions of The Royal Society A,, 365: 2951-2967, DOI: 10.1098/rsta.2007.0003.

Aravindaram K., Yang N.S., (2009). Gene gun delivery systems for cancer vaccine approaches, Methods Mol. Biol., 542: 167-178

Armaleo D., Ye G.N., Klein T.M., Shark K.B., Sanford J.C., Johnston S.A., (1992). Biolistic nuclear transformation of Saccharomyces cerevisiae and other fungi, Curr. Genet., 17:97-103

Arora A., Prausnitz M.R., Mitragotri S., (2008) Micro-scale devices for transdermal drug delivery, Int. J. Pharm. 364:227-236

Badran, M. M., Kuntsche, J., Fahr, A., (2009). Skin Penetration Enhancement by a 752 Microneedle Device (Dermaroller ${ }^{\circledR}$ ) in vitro: Dependency on Needle Size and Applied 753 Formulation, Pharm Sci., 36: 511- 523.

755 Bal S.M., Caussin J., Pavel S., Bouwstra J.A. (2008). In vivo assessment of safety of 756 microneedle arrays in human skin, European Journal of Pharmaceutical Sciences, 35(3): 757 193-202. 
759 Bastian S., Busch W., Kuhnel D., Springer A., Holke R., Scholz S., Pompe W., Gelinsky M., 760 Potthoff A., Richter V., Ikonomidou C., Schirmer K., (2009). Toxicity of tungsten carbide and 761 cobalt-doped tungsten carbide nanoparticles in mammalian cells in vitro, Environ. Health 762 Perspect.,117(4): 530-536

763

Bellhouse B.J., Sarphie D.F., and Greenford J.C., (1994). Needleless syringe using supersonic gas flow for particle delivery, Patent: US5899880 A, United States Patent

Bellhouse B.J., Bell J., Millward H.R., Phillips M.J., Nabulsi S.M., (2003). Particle delivery, US Patent: US 6592545 B1, United States Patent

769

Bellhouse B.J., Greenford J.C., Sarphie D.F., (2006). Particle delivery, Patent: EP 1637173 A2 771

Belyantseva I.A., (2009). Helios Gene Gun-Mediated Transfection of the Inner Ear Sensory Epithelium, Auditory and Vestibular Research: Methods and Protocols, Chapter 7, Editor Sokolowski B., 493: 103-123

775

Bennett A.M., Phillpotts R.J., Perkins S.D., Jacobs S.C., Williamson E.D., (1999). "Gene gun mediated vaccination is superior to manual delivery for immunisation with DNA vaccines expressing protective antigens from Yersinia pestis or Venezuelan Equine Encephalitis virus", Vaccine, 18(7-8): 588-596.

Bio-Rad Laboratories, (2013). USA. (also see, http://www.bio-rad.com/)

Biopex,

(2013).

SJ-500

Portable

gene

gun

787 (http://www.biopex.com/SJ-500-Portable-gene-gun-28-10.html) 
Bryan M., Guyach S., Norris K.A., (2013). Biolistic DNA vaccination against trypanosome infection, Methods Mol. Biol., 940: 305-315

792 Cao Y., Zhao B., Han Y.H., Zhang J., Li X.Z., Qiu C.H., Wu X.J., Hong Y., Ai D.Z., Lin J.J., Fu 793 Z.Q., (2013). Gene gun bombardment with DNA-Coated Golden particles enhanced the 794 protective effect of a DNA vaccine based on thioredoxin glutathione reductase of schistosoma 795 japonicum, BioMed. Research International, 2013: 952416, DOI: 10.1155/2013/952416.

797 Chabrai F., Bouris K., Jones T., Barrow D., Allender C., Hann A., Brain K., Birchall J., (2004). 798 "Microfabricated silicon microneedles for nonviral cutaneous gene delivery". British Journal of Dermatology, 150(5): 869-877

800

801 Chen B., Wei J., Tay F.E.H., Wong Y.T., Iliescu C., (2008). Silicon microneedle array with biodegradable tips for transdermal drug delivery, Microsystem Technologies, 14: 1015-1019.

803

804 Chen D., Maa Y., Haynes J.R., (2002). Needle-free epidermal powder immunization. Expert 805 Rev. Vaccines, 1(3): 89-100

806

807 Chen P.C., Hsieh S.J., Chen C.C., Zou J., (2013). A three-diemsional enormous surface area 808 aluminium microneedle array with nanoporous structure, Journal of Nanomaterials, doi:

$809 \quad \underline{10.1155 / 2013 / 164953 \text { (in press) }}$

810

811 Christou P., Mccabe D.E., Swain W.F., (1990). "Soybean genetic-engineering commercial 812 production of transgenic plants", Trends in biotechnology, 8: 145 -151

814 Coulman S., Allender C., Birchall J., (2006). "Microneedles and other physical methods for 815 overcoming the stratum corneum barrier for cutaneous gene therapy", Ther. Drug Carrier 816 Syst., 23(3): 205-258 
818 Da'dara A.A., Skelly P.J., Fatakdawala M., Visovatti S., Eriksson E., Harn D.A., (2002).

819 Comparative efficacy of the schistosoma mansoni nucleic acid vaccine, sm23, following

820 microseeding or gene gun delivery, Parasite Immunology, 24: 179-187

821

822 Davis, S.P., Prausnitz, M.R., Allen, M.G., (2003). Fabrication and characterization of Laser

823 Micromachined Hollow Microneedles. The $12^{\text {th }}$ Int. Conf. Solid states Sensor, Actuators and

824 Microsystems. Boston.

825

826 Davidson A,, Al Qallaf B,, Das D.B., (2008). Transdermal Drug Delivery by Coated

827 Microneedles: Geometry Effects on Effective Skin Thickness and Drug Permeability, Chemical

828 Engineering Research and Design, 86: 1196-1206, DOI: 10.1016/j.cherd.2008.06.002.

829

830 Davis S.P., Landis B.J., Adams Z.H., Allen, M.G., Prausnitz, M.R., (2004). Insertion of 831 microneedles into tissue: measurement and prediction of insertion force and needle fracture 832 force, Journal of Biomechanics, 37: 1155-1163

833

834 Dehn J., (1987). A Unified theory if penetration, International journal of impact engineering, $\mathbf{5}$ : 239-248

836

Disegi J.A., Eschbach L., (2000). Stainless steel in bone surgery, Injury, 31(4): 2-6

838

839 Donnelly R.F., Raj S.T.R., Woolfson A.D., (2010a). Micronneedle-based drug delivery systems: microfabrication, drug delivery, and safety, Drug Deliv., 17(4): 187-207

841

842 Donnelly R.F., Garland M.J., Morrow D.I.J., Migalska K., Singh T.R.R., Majithiya R., Woolfson 843 D.A., (2010b). Optical coherence tomography is a valuable tool in the study of the effects of 844 microneedle geometry on skin penetration characteristics and in-skin dissolution, Journal of 845 Controlled Release, 147: 333-341.

846

847 Donnelly R.F., Majithiya R., Singh T.R.R., Morrow D.I.J., Garland M.J., Demir Y.K., Migalska

848 K., Ryan E., Gillen D., Scott C.J., Woolfson A.D., (2011). Design, optimization and 
characterisation of polymeric microneedle arrays prepared by a novel laser-based

850 micromoulding technique, Pharm. Res., 28: 41-57

851

852 Donnelly R.F., Garland M.J., Singh T.R.R., Migalska K., Majithiya R., McCrudden C.M., Kole

853 P.L., Mahmood T.M.T., McCarthy H.O., Willfson A.D., (2012). Hydrogel-Forming microneedle

854 array for enhanced transdermal drug delivery, Adv. Funct. Mater., 22:4879-4890

855

856 Ettinger M., Peckl S.D., Gruber C., Laimer M., Thalhamer J., Hintner H., Gratz I.K., Bauer

857 J.W., (2012). Transcutaneous gene gun delivery of hNC16A induces BPAG2-Specific

858 tolerance, Journal of Investigative Dermatology, 132(6):1665-1671

859

860 Fernandez L.J., Altuna A., Tijero M., Gabriel G., Villa R., Rodriguez M.J., Batlle M., Vilares R.,

861 Berganzo J., Blanco F.J., (2009). Study of functional viability of SU-8-based microneedles for

862 neural applications, J. Micromech. Microeng. 19: doi:10.1088/0960- 1317/19/2/025007.

863

864 Gattiker G.E., Kaler K.V.I.S., Mintchev M.P., (2005). "Electronic mosquito: designing a 865 semi-invasive microsystem for blood sampling, analysis and drug delivery applications",

866 Microsystem Technologies, 12(1-2): 44-51

867

868 Gardeniers H.J.G.E., Luttge R., Berenschot E.J.W. de Boer M.J., Yeshurun S.Y., Hefetz M., 869 van't Oever R., van den Berg A., (2003). "Silicon Micromachined Hollow Microneedles for

870 Transdermal Liquid Transport". Journal of Microelectromechanical Systems, 12(6): 855-862

871

872 Glenn G.M., Kenney R.T., Ellingsworth L.R., Frech S.A., Hammond S.A., Zoeteweweij J.P.,

873 Transcutaneous immunization and immunosticmulant strategies: capitalizing on the

874 immunocompetence of the skin, Expert Rev., Vaccines, 2(2): 253-267

875

876 Gill, H.S., Denson, D.D., Burris, B.A., Prausnitz, M.R., (2008). Effect of Microneedle design on 877 pain in Human subjects, Clin. J. Pain., 24:585-594.

878 
880 Shan W.X., (2011). Rust secreted protein Ps87 is conserved in diverse fungal pathogens and

881 contains a RXLR-like motif sufficient for translocation into plant cells, PLoS One., 6(11):

882 e27217

883

884 Gupta J., Park S.S., Bondy B., Felner E.I,, Prausnitz M.R., (2011a). Infusion pressure and pain

885 during microneedle injection into skin of human subjects, Biomaterials, 32: 6823-6831

886

887 Gupta J., Gill H.S., Andrews S.N., Prausnitz M.R., (2011b). Kinetics of skin resealing after

888 insertion of microneedles in human subjects, Journal of Controlled Release, 154: 148-155

889

890 Han M., Hyun D.H., Park H.H., Lee S.S.L., Kim C.H., Kim C.G., (2007). A novel fabrication

891 process for out-of-plane microneedle sheets of biocompatible polymer, J. Micromech.

Microeng., 17: 1184-1191.

893

894 Han R., Peng X., Reed C.A., Cladel N.M., Budgeon L.R., Pickel M.D., Christensen N.D., 895 (2002). Gene gun-mediated intracutaneous vaccination with papillomavirus E7 gene delays 896 cancer development of papillomavirus-induced skin papillomas on rabbits, Cancer Detect 897 Prev., 26(6): 458-467

898

Han T., Das D.B., (2013). Permeability enhancement for transdermal delivery of large

900 molecule using low-frequency sonophoresis combined with microneedles, Journal of

901 Pharmaceutical Science, 102(10): 3614-3622

902

903 Han X., Wang D.K., Wang Y., (2008). "Development of Transdermal Delivery System of

904 Microneedles", Chinese Journal of Pharmaceutics, 6(5): 296-300

905

906 Haq M.I., Smith E., John D.N., Kalavala M., Edwards C., Anstey A., Morrissey A., Birchall J.C., 907 (2009). Clinical administration of microneedles: skin puncture, pain and sensation, Biomed.

908 Microdevices, 11: 35-47

909 
911 and the ballistic impact of microparticles, Phys. Med. Biol., 50(19): 4567-4580

913 Henry S., McAllister D.V., Allen M.G., Prausnitz M.R., (1998). Micromachined needles for the

914 transdermal delivery of drugs, Proc. IEEE Micro Electro Mechanical Systems, MEMS'98,

915 Heidelberg Germany, 25(29): 494-498

916

917 Henry, S., McAllister, D.V., Allen, M.G., Prausnitz, M.R. (1998). Microfabricated microneedles:

918 a novel approach to transdermal drug delivery, J. Pharm. Sci., 87: 922-925.

920 Holbrook, K.A. (1994). Ultrastructure of the Epidermis: Chapter 1 of the Keratinocyte 921 Handbook, edited by Leigh, I.M. and Lane, E.B., Watt, F.M., Cambridge, Great Britain, 922 Cambridge University Press. : 3-39.

923 Holbrook, K. A., Odland, G.F. (1974). Regional Differences in the thickness (cell layers) of the 925 human stratum corneum: an ultrasound analysis, J Invest Dermatol., 62: 415-422. Hou L.Y., Wang P.Y., Kong F.T., Park H., Kobiro K. and Ohama T., (2013). Mesoporous TiO2 nanoparticles: A new material for biolistic bombardment, Phycological Research, 61: 58-60 gene gun, Journal of Marine Science and Technology, 19(6): 686-692 protein transfection into cells, Scientific Reports, 2: 289

937 the Eye Using Hollow microneedles, Pharm Re.s, 26: 395-403. 
942 Kaushik S., Hord A.H., Denson D.D., McAllister D.V., Smitra S., Allen M.G., Prausnitz M.R.,

943 (2001). Lack of pain associated with microfabricated microneedles, Anesth. Analg., 92(2):

$944 \quad 502-504$

945

946 Kendall M.A.F., Carter F.V., Mitchell T.J., and Bellhouse B.J., (2001). Comparison of the

947 transdermal ballistic delivery of micro-particle into human and porcine skin, Proceedings of the

948 23rd Annual International Conference of the IEEE: 2991-94

949

950 Kendall M.A.F., (2002). The delivery of particulate vaccines and drugs to human skin with a

951 practical, hand -held shock tube-based system, Shock Waves, 12: 23-30

952

953 Kendall M.A.F., Quinlan N.J., Thorpe S.J., Bellhous B.J., Ainsworth R.W. (2004a).

954 Measurements of the gas and particle flow within a converging-diverging nozzle for high speed 955 powdered vaccine and drug delivery, Exp. Fluids, 37: 128-36

956

957 Kendall M.A.F., Rishworth S., Carter F., Mitchell T., (2004b). Effects of relative humidity and 958 ambient temperature on the ballistic delivery of micro-particles to excised porcine skin, $\mathrm{J}$. 959 Invest. Dermatol. 122:739-746

960

961 Kendall M.A.F., Mitchell T.J., Costigan G., Armitage M., Lenzo J.C., Thomas J.A., Garnier

962 C.V., Zosky G.R., Turner D.J., Stumables P.A., Sly P.D., Holt P.G., Thomas W.R., (2006).

963 Downregulation of IgE antibody and allergic responses in the lung by epidermal biolistic

964 microparticle delivery, J. Allergy Clin. Immunol., 117: 275-282

965

966 Kendal M.A.F., (2006). Engineering of needle-free physical methods to target epidermal cells

967 for DNA vaccination, Vaccine, 24: 4651-4656

968

969 Kim Y.C., Quan F.S., Compans R.W., Kang S.M., Prausnitz M.R., (2010). Formulation of 970 microneedles coated with influenza virus-like particle vaccine, AAPS PharmSciTech,, 11(3): $971 \quad 1193-1201$ 
973 Kim Y.C., Park J.H., Prausnitz M.R, (2012). Microneedles for drug and vaccine delivery,

974 Advanced Drug Delivery Reviews, 64: 1547-1568

975

976 Klein T.M., Wolf E.D., Wu R., Sanford J.C., (1987). High-velocity microprojectiles for delivery

977 of nucleic acids into living cells, Nature(London), 327: 70-73

978

979 Klein T.M., Arentzen R., Lewis P.A., McElligott F.S., (1992). Transformation of microbes, 980 plants by particle bombardment, Biotechnology, 10: 286-291

981

982 Koelmans W.W., Krishnamoorthy G., Heskamp A., Wissink J., Misra S., Tas N., (2013).

983 Microneedle Characterization using a double-layer skin simulant, Mechanical Engineering

984 Research, 3(2): 51-63

985

986 Kuriakose B., Toit E.S., Jordaan A., (2012). Transient gene expression assays in rose tissues

987 using a Bio-Rad Helios hand-held gene gun, South African Journal of Botany, 78: 307-311

988

989 Kuriyama S., Mitoro A., Tsujinoue H., Nakatani T., Yoshiji H., Tsujimoto T., Yamazaki M.,

990 Fukui H., (2000). Particle-mediated gene transfer into murine livers using a newly developed

991 gene gun, Gene Ther., 7: 1132-1136.

992

993 Liu Y., Kendall M.A.F., (2004a). Numerical study of a transient gas and particle flow in a 994 high-speed needle-free ballistic particulate vaccine delivery system, Journal of Mechanics in 995 Medicine and Biology, 4(4): 559-578

996

997 Liu Y., Kendall M.A.F., (2004b). Numerical simulation of heat transfer from a transonic jet 998 impinging on skin for needle-free powdered drug and vaccine delivery, Proceedings of the 999 institution of mechanical engineers, part C: J. Mech, Eng, Sci,, 218(11): 1373-1383

1001 Liu Y., Kendall M.A.F., (2006). Numerical analysis of gas and micro-particle interactions in a 1002 hand-held shock tube device, Biomed Microdevices, 8: 341-351 
1004 Liu Y., (2006). Physical-mathematical modeling of fluid and particle transportation for DNA vaccination, International Journal of Engineering Science, 44(15-16): 1037-1049

1007 Liu Y., (2007). Impact studies of high-speed micro-particle following biolistic delivery, IEEE

Liu Y., Truong N.K., Kendall M.A.F., Bellhouse B.J., (2007). Characteristics of a micro-biolistic 1011 system for murine immunological studies, Biomed. Microdevices, 9:465-474

1013 Liu Y., Costigan G., Bellhouse B.J., (2008). Swirling effects on the performance of the 1014 micro-particle acceleration and penetration: parametric studies, Powder Technol. 183: $1015 \quad 189-195$

1017 Liu Y., (2008). Simulation of transient shock motion within a biological contoured shock tube 1018 system, Physica D: Nonlinear Phenomena, 237(2): 233-242 $874-880$ gene delivery system, International Journal of Pharmaceutical Investigation, 3(1): 1-7

1029 Marks J.G., Miller J.J., Lookingbill D.P., (2006). Principles of Dermatology, 4 editions, 1030 Saunders Elsevier: 1-7, ISBN: 1416031855 
1035 Martanto W., Davis S.P., Holiday N.R., Wang J., Gill H.S., Prausnitz M.R. (2004). Transdermal delivery of Insulin using microneedles in vivo, Pharmaceutical Research, 21: 947-952.

Matteucci M., Fanetti M., Casella M., Gramatica F., Gavioli L., Tormen M., Grenci G., De Angelis F., Di Fabrizio E. (2009). Poly vinyl alcohol re-usable masters for microneedle replication. Microelectronic Engineering, 86(4-6): 752-756, doi:10.1016/j.mee.2009.01.068

Matthews K., Bailey S.L., Gossner A.G., Watkins C., Dalziel R.G., Hopkin J., (2007). Gene

1043 gun-delivered pGM-CSF adjuvant induces enhanced emigration of two dendritic cell subsets

1044 from the skin, Scand. J. Immunol., 65(3):221-229

Mcallister D.V., Allen M.G., (2000). Prausnitz MR. Microfabricated microneedles for gene and drug delivery, Annual Review Biomedical Engineering, 2: 289 -313.

1048

McAllister D.V., Wang P.M., Davis S.P., Park J.H., Canatella P.J., Allen M.G., Prausnitz, M.R. (2003). Microfabricated needles for transdermal delivery of macromolecules and Meacham J.M., Durvasula K., Degertekin F.L., Fedorov A.G., (2013). Physical methods for 1054 intracellular delivery: Particle aspects from laboratory use to industrial-scale processing, 1055 Journal of Laboratory Automation, DOI: 10.1177/2211068213494388

1057 Memon S., Pathan D.N., Ziyaurrrahman A.R., Bagwan A., Sayed B., (2011). Microneedle as a 1058 novel drug delivery system: A review, Internation Research Journal of Pharmacy, 2(2): 72-77

1061 microparticles for DNA/Drug delivery, PLOS ONE, 7(11): e50823

1063 Mikolajewska P., Donnelly R.F., Garland M.J., Morrow D.I.J., Singh T.R.R., Lani V., Moan J., 1064 Juzeniene A., (2010). Microneedle pre-treatment of human skin improves 5-aminolevulininc 
acid (ALA) and 5-aminolevulinic acid methyl ester (MAL) induced PpIX production for topical photodynamic therapy without increase in pain or erythema, Pharm. Res., 27: 2213-2220

Mikszta J.A., Alarcon J.B., Brittingham J.M., Sutter D.E., Pettis R.J., Harvey N.G., (2002). Improved genetic immunization via micromechanical disruption of skin-barrier function and targeted epidermal delivery, Nat. Med., 8: 415-419.

Mitchell T.J., Kendall M.A.F., Bellhouse B.J., (2003). A ballistic study of micro-particle penetration to the oral mucosa, International Journal of Impact Engineering, 28: 581-599

Mohammed D., Matts P.J., Hadgraft J., Lane M.E., (2012). Variation of stratum corneum biophysical and molecular properties with anatomic site, The American Association of Pharmaceutical Scientists, 14(4): 806-812

Nagata T., Koide Y., (2010). Induction of specific $\mathrm{CD}^{+} \mathrm{T}$ cells against intracellular bacteria by

1080 CD $8^{+}$T-cell-oriented immunization approaches, Journal of Biomedicine and Biotechnology, 1081 2010: 764542, DOI: 10.1155/2010/764542.

1082

1083 Nayak A., Das D.B., (2013). Potential of biodegradable microneedles as a transdermal delivery vehicle for lidocaine, Biotechnology Letters, 35(9): 1351-1363

1085 Nguyen-Hoai T., Hohn O., Vu M.D., Baldenhofer G., Sayed A.M.S., Dorken B., Norley S., Lipp M., Pezzutto A., Westermann J., (2012). CCL19 as an adjuvant for intradermal gene gun

1088 immunization in a Her2/neu mouse tumor model: improved vaccine efficacy and a role for $B$ 1089 cells as APC, Cancer Gene Ther., 19(12): 880-887

1091 O'Brien J.A., Lummis S.C.R., (2011). Nano-biolistics: a method of biolistic transfection of cells 1092 and tissues using a gene gun with novel nanometer-sized projectiles, BMC Biotechnology, 11; 109366 
O'Brien J.A., Lummis S.C.R., (2007). Diolistics: incorporating fluorescent dyes into biological samples using a gen gun, Trends in Biotechnology, 25(11): 530-534

1098 O'Brien J.A., Lummis S.C.R., (2006). Biolistic transfection of neuronal cultures using a hand-held gene gun, Nat. Protoc. 1(2): 977-981

1101 Oh, j., Park, H., Do, K., Han, M., Hyun, D., Kim, C., Kim,C., Lee, S., Hwang, S., Shin, S., Cho, 1102 C. (2008). Influence of the delivery systems using a microneedle array on the permeation of a 1103 hydrophilic molecule, calcein. European Journal of Pharmaceutics and Biopharmaceutica. 69: 1104 1040-1045.

Olatunji, O., Das, D.B., (2010). Painless Drug delivery using microneedles. Current technologies to increase the transdermal delivery of drugs (Editor: Joan Escober Chavez).

1109 http://www.benthamdirect.org/pages/b_getarticlebybook.php). ISBN:978-1-60805-191-5

Olatunji, O., Das, D.B., (2011). Drug delivery using Microneedles. Comprehensive 1112 Biotechnology (Editor: Zhanfeng Cui). 2nd Edition, MS number 501. MRW, Elsevier, The 1113 Boulevard, Langford Lane, Oxford, United Kingdom. ISBN: 13: 978-0-444-53352-4 Olatunji, O, Das, DB, Nassehi, V (2012) Modelling transdermal drug delivery using microneedles: Effect of geometry on drug transport behaviour, Journal of Pharmaceutical Sciences, 101(1): 164-175, ISSN: 0022-3549. DOI: 10.1002/jps.22736.

1119 Olatunji O., Das D.B., Garland M.J., Belaid L., Donnelly R.F., (2013). Influence of Array interspacing on the force required for successful microneedle skin penetration: theoretical and

1121 practical approaches, Journal of pharmaceutical science, 102(4): 1209-1221

1123 Palastanga N., Field D., Soames R.W., (2006). Anatomy and human Movement: Structure and

1124 function, $5^{\text {th }}$ edition, London: Elsevier Health Science, ISBN-13: 9780750688147 
1126 Park J.H., Allen M.G., Prausnitz M.R., (2005). Biodegradable polymer microneedles:

1127 fabrication, mechanics and transdermal drug delivery, Journal of Controlled Release, 104(1):

1128 51-66

1129

1130 Park J.H., Allen M.G., Prausnitz M.R., (2006). Polymer microneedles for controlled-release

1131 drug delivery, Pharm. Res., 23: 1008-1019.

1132

1133 Parker E.R., Rao M.P., Turner K.L., Meinhart C.D., MacDonald N.C. (2007). Bulk 1134 micromachined titanium microneedles, Journal of Microelectromechanical System, 16: 1135 289-295.

1137 Parker, F. (1991). Structure and Function of the Skin: Chapter 1 in Dermatology edited by

1138 Orkin, M. and Maibach, H. I. and Dahl, M. V., 1st edition (Norwalk, Connecticut: Appleton and 1139 Lange).

1140

1141 Phipps, J. B. Padmanabhan, R. V. Lattin, G. A. (1988). Transport of Ionic Species Through 1142 Skin. Solid State Ionics, 28: 1778-1783.

1143

1144 Prausnitz M.R., Langer R., (2008). Transdermal drug delivery, Nat. Biotech., 26(11): $1145 \quad 1261-1268$

1146

1147 Qi P., Chen G.G., Wei P., (2007). "Research and Development of Microneedles for 1148 Transdermal Drug Delivery", Journal of Nanjing University of Technology (Natural Science 1149 Edition), 29(4): 57-63

1151 Quan F.S., Kim Y.C., Compans R.W., Prausnitz M.R., Kang S.M., (2010). Does sparing 1152 enabled by skin immunization with influenza virus-like particle vaccine using microneedles, $J$. 1153 Control Release, 147(3): 326-332 
1155 Quinlan N.J., Kendall M.A.F., Bellhouse B.J., Ainsworth R.W., (2001). Investigations of gas 1156 and particle dynamics in first generation needle-free drug delivery device, Shock Waves, 10: $1157 \quad 395-404$

Raju P.A., Truong N.K., Kendall M.A.F., (2006). Assessment of epidermal cell viability by near infra-red two-photon microscopy following ballistic delivery of gold micro-particles, Vaccine,

Rao W., (2010). A proteomic analysis of lipid raft and GPI anchored protein in Caenorhabditis elegans, University of Leeds (UK), Thesis for the degree of Doctor of Philosophy

Rasel M.A.I., Taher M.A., Kim H.D., (2013). A study on the gas-solid particle flows in a needle-free drug delivery device, Journal of Thermal Science, 22(4): 340-344

Rinberg D., (2005). Pneumatic capillary gun for ballistic delivery of micro-particles, Applied Physics Letters, 87: 014103

Rosi N.L., Giljohann D.A., Thaxton C.S., Lytton-Jean A.K., Han M.S., Mirkin C.A., (2006).

1173 Oligonucleotide-modified gold nanoparticles for intracellular gene regulation, Science, 312: $1027-1030$

1176 Russell J.A., Roy M.K., Sanford J.C., (1992). Physical trauma and tungsten toxicity reduce the efficiency of biolistic transformation, Plant Physiol., 98: 1050-1056

1179 Sachdeva V., Banga A.K., (2011). Microneedles and their applications, Recent Pat. Drug Delivery Formulation, 5: 95-132

1182 Sakai T., Hisaeda H., Nakano Y., Ishikawa H., Maekawa Y., Ishii K., Nitta Y., Miyazaki J., 1183 Himeno K., (2000). Gene gun-mediated delivery of an interleukin-12 expression plasmid 1184 protects against infections with the intracellular protozoan parasites leishmania major and 1185 Trypanosoma cruzi in mice, Immunology, 99: 615-624 
1187 Sanford J.C., Klein T.M., Wolf E.D., Allen N., (1987). Delivery of substances into cells and 1188 tissues using a particle bombardment process, Particulate Science and Technology, 5(1): $1189 \quad 27-37$

1191 Sanford J.C., Smith F.D., Russell J.A., (1993). Optimizing the biolistic process for different 1192 biological applications, Methods Enzymol., 217: 483-509

1194 Satish D., (2009). In vitro manipulation of pollen for transformation in cotton and tomato, 1195 University of Agricultural Sciences (India), Thesis for the degree of Doctor of Philosophy.

1197 Sato H., Hattori S., Kawamoto S., Kudoh I., Hayashi A., Yamamoto I., Yoshinari M., Minami 1198 M., Kanno H., (2000). In vivo gene gun-mediated DNA delivery into rodent brain tissue, 1199 Biochem. Biophys. Res. Commun. 270(1): 163-170.

1201 Schaefer H., Redelmeier T.E. (1996). Skin barrier: Principles of percutaneous absorption, New 1202 York, Karger.

1203

1204 Shah U.U., Roberts M., Gul M.O., Teleu C., Beresford M.W., (2011). Needle-free and 1205 microneedle drug delivery in children: a case for disease-modifying antirheumatic drugs 1206 (DMARDs), International Journal of Pharmaceutics, 416: 1-11 Smith F.D., Harpending P.R., Sanford J.C., (1992). Biolistic transformation of prokaryotes: factors that affect biolistic transformation of very small cells. J. Gen. Microbiol., 138:239-248

1211 Silpi C., Manish B., Kumar T.R., (2011). Microneedles in transdermal drug delivery: An unique 1212 painless option, International Research Journal of Pharmacy, 2(4): 72-78

1214 Singh R., Dahotre N.B., (2007). Corrosion degradation and prevention by surface modification 1215 of biometallic materials, J. Mater. Sci. Mater. Med., 18(5):725-751 
1217 Soliman S.M. (2011). Micro-particle and Gas Dynamics in an Axi-symmetric Supersonic 1218 Nozzle, University of Cincinnati (Cincinnati, USA), Thesis for the degree of Doctor of 1219 Philosophy in Aerospace Engineering.

1221 Soliman S.M., Abdallah S., (2011a). CFD investigation of powdered vaccine and gas dynamics 1222 in biolistic gun, Powder Technology, 214: 135-142

1223

1224 Soliman S.M., Abdallah S., Gutmark E., Turner M.G., (2011b). Numerical simulation of 1225 microparticles penetration and gas dynamics in an axi-symmetric supersonic nozzle for 1226 genetic vaccination, Powder Technology, 208: 676-683

Stoeber B., Liepmann D., (2000). Fluid injection through out-of-plane microneedles, 1229 Proceedings of the 1st Annual International IEEE-EMBS Special Topic Conference on Microtechnologies in Medicine and Biology, Lyon, France, 14: 224-228.

1232 Sung H.W., Chen M.C., Lee P.W., Tu H.S., (2011). Nanoparticles for protein/peptide delivery 1233 and delivery means thereof, Patent No. US7901711 B1 (Granted), United States Patent, USA 1234

1235 Svarovsky S., Borovkov A., Sykes K., (2008). Cationic gold microparticles for biolistic delivery of nucleic acids, Biotechniques, 45(5): 535-540

1238 Tekeuchi Y., Doston M., Keen N.T., (1992). Plant transformation: a simple particle 1239 bombardment device based on flowing helium, Plant Mol. Biol., 18: 835-839

1241 Thomas J.L., Bardou J., Mauchamp B. et al, Chavancy Gerard (2001). A helium burst biolistic 1242 device adapted to penetrate fragile insect tissues, Journal of Insect Science, 1(9): 1-10 1243

1244 Tortora G.J., Derrickson B.H., (2011). Principles of Anatomy and Physiology, 13 edition, Wiley, 1245 ISBN-13: 978-0470565100 
1247 Trainer A.T., Alexander M.Y., (1997). Gene delivery to the epidermis, Human Molecular 1248 Genetics, 6(10): 1761 - 1767

1250 Truong N.K., Liu Y., Kendall M.A.F., (2006). Gas and particle dynamics of a contoured shock 1251 tube for pre-clinical micro-particle drug delivery, Shock Waves, 15: 149-164

1253 Tuan-Mahmood T.M., McCrudden M.T.C., Torrisi B.M., McAlister E., Garland M.J., Singh 1254 T.R.R., Donnelly R.F., (2013). Microneedles for intradermal and transdermal drug delivery, 1255 European Journal of Pharmaceutical Sciences, doi: 10.1016/j.ejps.2013.05.005. (in press)

1257 Uchida M., Li X.W., Mertens P., Alpar H.O., (2009). Transfection by particle bombardment: 1258 Delivery of plasmid DNA into mammalian cells using gene gun, Biochim. Biophys. Acta., 1259 1790(8): 754-764

1261 Valenstein J.C., (2012). Developing nanotechnology for biofuel and plant science applications, 1262 lowa State Univeristy (USA), Thesis for the degree of Doctor of Philosophy

1264 Verbaan, F.J., Bal, S.M., van den Berg, D.J., Dijksman, J.A., van Hecke, M., Verpoorten, H., 1265 van den Berg, A., Luttge, R., Bouwstra, J.A. (2008). Improved piercing of microneedle arrays 1266 in dermatomed human skin by an impact insertion method, Journ. Contrl. Rel., 128: 80-88.

1268 Williams R.S., Johnston S.A., Riedy M., DeVit M.J., McElligott S.G., Sanford J.C., (1991). 1269 Introduction of foreign genes into tissues of living mice by DNA-coated microprojectiles, Proc. 1270 Natl. Acad. Sci. U.S.A., 88: 2726-2730 Xia J.X., Martinez A., Daniell H., Ebert S.N., (2011). Evaluation of biolistic gene transfer 1273 methods in vivo using non-invasive bioluminescent imaging techniques, BMC Biotechnology, 
1277 particle-mediated epidermal delivery of an influenza DNA vaccine in ferrets, Methods Mol. Biol.,

940: $223-237$

Yang N.S., Burkholder J., Roberts B., Martinell B., McCabe D., (1990). In vivo and in vitro gene transfer to mammalian somatic cells by particle bombardment, Proc. Natl. Acad. Sci. U.S.A., 87: 9568-9572

Yen M.C., Lai M.D., (2013). Biolistic DNA delivery to mice with the low pressure gene gun, Methods Mol. Biol., 940:169-174

Yoshida Y., Kobayashi E., Endo H., Hamamoto T., Yamanaka T., Fujimura A., Kagawa Y., 1288 (1997). Introduction of DNA into rat liver with a hand-held gene gun: Distribution of the expressed enzyme, [32P] DNA, and Ca2+ flux, Biochem. Biophys. Res. Commun. 234(3): 695 -700 .

Yoshimitsu Y., Tanaka K., Tagawa T., Nakamura Y., Matsuo T., Okamoto S., (2009), Improvement of DNA/Metal Particle Adsorption in Tungsten-Based Biolistic Bombardment; Alkaline $\mathrm{pH}$ is Necessary for DNA Adsorption and Suppression of DNA Degradation, Journal of Plant Biology, 52: 524-532.

Yuzhakov V.V., (2008). Tissue conforming microneedle array and patch for transdermal drug delivery or biological fluid collection, World Intellectual Property Organization, Patent: WO 2008/067290 A2;

Zhang M.J., Tao W.M., Pianetta P.A., (2007). Dynamics modeling of biolistic gene guns, Phys.

Zhang D.W., Das D.B., Rielly C.D., (2013a). An experimental study of microneedles assisted 1305 micro-particle delivery using a model system, Journal of Pharmaceutical Science, 102(10): 
1308 Zhao H.Y., Avenarius M.R., Gillespie P.G., (2012). Improved biolistic transfection of hair cells, 1309 PLOS ONE, 7(10): e46765

1311 Zhao Y., J., Zhang J.,Y., Yang X.,L., (2006). "Design and Manufacture of Microneedles Array 1312 for Transdermal Drug Delivery", Chinese Journal of Medical Instrumentation, 30(1): 33-38

1314 Zhou F., (2000). High-pressure Gas Gene Gun, Chinese Patent No. CN 1262323A (Granted), 1315 State Intellectual Property Office of the P.R. China, China

1317 Zhou F., (2007). Liquid Gene Gun, Chinese Patent No.CN 189217A (Granted), State 1318 Intellectual Property Office of the P.R. China, China

Zhou W.Z., (1995). Gene Gun, Chinese Patent No. CN 2196119Y (Granted), State Intellectual 1321 Property Office of the P.R. China, China

Zhu, M., Chen, Y., Wang, Z. Lu, Y., Ge, H., Tang, Y. (2012). Fabrication Method for Hollow Microneedles for Drug Delivery. Nanjing University, Patent US 8137736 B2 (Granted), United States Patent, USA

1327 Ziegler A.S., (2008). Needle-free delivery of powdered protein vaccine: a new and rapidly developing technique, J. Pharm. Innov., 3: 204-213

Zilony N., Tzur-Balter A., Segal E., Shefi O., (2013). Bombarding Cancer: Biolistic delivery of 1331 therapeutics using porous Si carriers, Scientific Reports, 3: article number 2499

1333 Zuraida A.R., Rahiniza K., Hafiza M.R.N., Roowi S., Zamri Z., Subramaniam S., (2010). 1334 Factors affecting delivery and transient expression of gusa gene in Malaysian indica rice MR 1335219 callus via biolistic gun system, African Journal of Biotechnology, 9(51):8819-8818. 